\title{
33. TECTONIC SYNTHESIS, DEEP SEA DRILLING PROJECT LEG 78A: STRUCTURAL EVOLUTION OF OFFSCRAPED AND UNDERTHRUST SEDIMENT, NORTHERN BARBADOS RIDGE COMPLEX ${ }^{1}$
}

\author{
J. Casey Moore, Earth Sciences and Marine Studies, University of California at Santa Cruz \\ and \\ Bernard Biju-Duval, Institut Français du Pétrole ${ }^{2}$
}

\begin{abstract}
Drilling and seismic reflection data in the Leg 78A area indicate offscraping of approximately the upper $200 \mathrm{~m}$ of the incoming sediment section and underthrusting of the subjacent sediment with the ocean crust. Approximately lithostatic fluid pressure was measured in a thrust fault splaying off the décollement separating the offscraped and underthrust sediment packages; this high fluid pressure apparently allows the underthrusting of the coherent sedimentary sequence beneath the décollement. Repetition of nannofossil zones defines at least five thrust or reverse faults in the offscraped sediment package penetrated at Sites 541 and 542. Restoration of the offscraped sections at these drill sites yields original thicknesses similar to the incoming sedimentary section, indicating that all major structural repetitions are recognized. Unfaulting of the drilled section suggests an average convergence rate of $0.7 \mathrm{~km} / \mathrm{Ma}(0.07 \mathrm{~cm} / \mathrm{yr}$. $)$. Distributed deformation arcward of the Leg 78A area probably absorbs the remainder of the 20-plus-km/Ma convergence between the Caribbean and North American plates. Thickening of the offscraped sedimentary section above an unbroken décollement landward of the Leg 78A area cannot be the result of underplating but must be explained by continuing imbrication of the offscraped sedimentary packages. The rate of thickening and hence rate of shortening decreases west of the deformation front. Deformation in the accretionary prism appears to be partitioned between small-scale faulting and fabric development, and discrete large-scale faults.

The hemipelagic to pelagic section offscraped in the Leg 78A area includes no terrigenous turbidites but does have numerous ash beds derived from the Lesser Antilles volcanic arc. Hence this sequence is dissimilar to siliciclastic-dominated subaerial terranes inferred to be ancient accretionary complexes. The underthrust sedimentary section is principally pelagic in character. Thrust and reverse faulting and the décollement tend to develop in or adjacent to underconsolidated Miocene smectitic clays, indicating stratigraphic control on faulting.
\end{abstract}

\section{INTRODUCTION}

Tectonic style at convergent margins can be encompassed between two end-members in which either accretion or subduction erosion is dominant (Scholl et al., 1980); a range of many intermediate types also occurs. For example, the Mariana Trench system apparently represents an erosional forearc where arc-derived volcanic rocks constitute nearly all sampled basement (Hussong, Uyeda, et al., 1982). Similarly, the entire incoming sedimentary section is subducted off Guatemala, perhaps with simultaneous or previous tectonic erosion (Aubouin, von Huene, et al., 1982). In contrast, the Middle America Trench off southern Mexico (Watkins, Moore, et al., 1982) and the Nankai Trough (Karig, Kagami, et al., 1983) are presently accreting sediment both at the base of the trench slope and perhaps also underplating it at depth beneath the accretionary prism. In general accretion is favored in areas of high sediment supply, whereas nonaccretion or subduction erosion occurs in regions characterized by little sediment on the incoming oceanic plate. The strength of the sediment on the incoming oceanic plate and the internal pore pressure of the sedi-

\footnotetext{
${ }^{1}$ Biju-Duval, B., Moore, J. C., et al., Init. Repts. DSDP, 78A: Washington (U.S. Govt. Printing Office).

Addresses: (Moore) Earth Sciences and Marine Studies, University of California at Santa Cruz, Santa Cruz, CA 95064; (Biju-Duval, present address) Centre pour l'Exploitation des Océans, 66 Avenue d'léna, 75116 Paris, France.
}

ment may also influence its partitioning between accretion and subduction (von Huene and Lee, 1983).

The Barbados Ridge complex is a prime example of a subduction complex developed by sediment accretion (e.g., Chase and Bunce, 1969; Westbrook et al., 1973; BijuDuval et al., 1978; Westbrook, 1982). Although the Lesser Antilles arc and associated Barbados Ridge complex are of intra-oceanic nature, much sediment is supplied longitudinally from South America. The Leg 78A drilling area, located along the northern part of the Barbados Ridge complex, is a region of modest sediment supply and moderate accretion. The principal goal of Leg $78 \mathrm{~A}$ was to penetrate the toe of the Barbados Ridge complex and thus provide a complete structural profile of the leading edge of the Caribbean Plate. Using stratigraphic information, we had hoped to determine whether the toe of the Barbados Ridge complex represents a gravity slide or offscraped oceanic deposits. Moreover, we wished to determine if an acoustically layered sequence that lies beneath the toe of the complex is made up of underthrust oceanic deposits. The composition of the acoustically layered sequence is of particular interest, because it may later be subducted and perhaps become involved in island-arc magma genesis. The Barbados Ridge complex shows significant variations in structural style from south to north (see the section on Tectonic setting later in chapter); accordingly an additional drilling objective was to sample geologically one end-mem- 
ber style. Our drilling unfortunately did not penetrate completely through the toe of the Barbados Ridge complex. However, the assemblage of six holes at three sites achieved many of our goals and an unexpected measurement of fluid pressure.

Because the language applicable to subduction zones is in constant flux we use terminology as follows: "Accretion" refers in general to the transfer of material from the underthrusting to overriding plate. "Offscraping" describes accretion at the seaward edge of the accretionary complex (Scholl et al., 1980). "Underplating" designates a process of mass addition at depth beneath the trench slope (Watkins et al., 1981). "Subduction" describes the subcrustal descent of sediment or crust of the lower plate beneath bedrock framework of a convergent margin (Scholl et al., 1980). Thus sediment may be "underthrust" beneath the seaward edge of the accretionary complex to be either underplated at depth or ultimately subducted.

\section{TECTONIC SETTING}

The Barbados Ridge subduction complex and associated Lesser Antilles volcanic arc compose the eastern margin of the Caribbean Plate. This arc-subduction complex pair is flanked on the west by the Grenada Basin, a back-arc basin (see discussion in Bouysse et al., this volume), and to the east by Atlantic ocean crust (Fig. 1). The igneous ocean crust can be traced using earthquakes to $200 \mathrm{~km}$ depth beneath the arc (Tomblin, 1975) and is underthrust at a rate variously estimated at 2 to $4 \mathrm{~cm} / \mathrm{yr}$. (Minster and Jordan, 1978; Sykes et al., 1983). The major forearc basins are the Tobago Trough and its northward continuation, the Lesser Antilles Trough. These basins contain more than $4 \mathrm{~km}$ of fill and become progressively more deformed to the east where they are incorporated into the Barbados Ridge complex.

The Lesser Antilles forearc is more than $450 \mathrm{~km}$ wide in the south and narrows to about $260 \mathrm{~km}$ in the vicinity

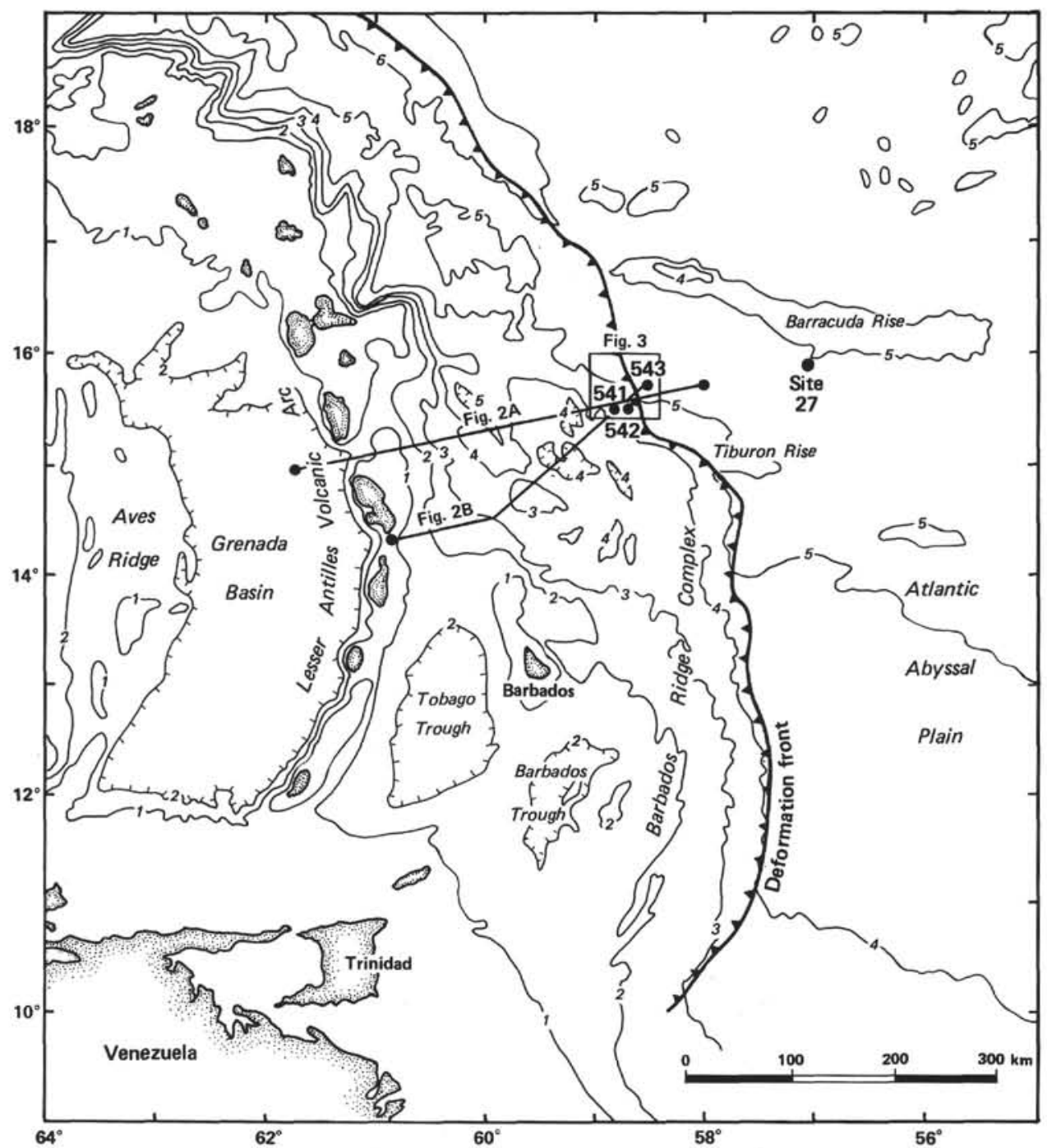

Figure 1. Regional location map. Note position of deformation front defining eastward boundary of Barbados Ridge complex, and Tiburon Rise underthrusting deformation front near Sites 541, 542, and 543. Water depth contours are in kilometers. 
of the Leg 78A transect (Figs. 1-3). The development of the Barbados Ridge complex is strongly influenced by a copious longitudinal sediment supply from South Ameri$\mathrm{ca}$. This large sediment supply has permitted accretionary progradation of the Barbados Ridge complex eastward over the former topographic trench. Hence, the eastward limit of this complex is defined by a deformation front characterized by folding and faulting of the adjacent basinal sedimentary section.

Recent multichannel seismic reflection surveys (BijuDuval et al., 1978; Mascle et al., in press; Westbrook et al., 1982; Westbrook et al., this volume) have elucidated the great extent, thickness, and structural variability of the Barbados Ridge complex. The variation in the thickness of sediment entering the subduction zone ranges from more than $5 \mathrm{~km}$ in the south to less than $1 \mathrm{~km}$ in the north near the Leg 78A area (Figs. 4 and 5). This sediment accumulation from the Orinoco and Amazon rivers tends to decrease northerly because of increasing distance from South American and the damming effects of topographic highs (e.g., Tiburon Rise and Barracuda Ridge; Fig. 1). The thickness of incoming sediment strongly influences structural style. South of $12^{\circ} 30^{\prime}$ and near $14^{\circ} 30^{\prime}$ the initial deformation is characterized by open, asymmetrical, eastward-verging folds separated by thrusts of similar vergence. In these areas a sequence of turbidites up to $6 \mathrm{~km}$ thick is being progressively deformed and accreted to the Barbados Ridge complex (Fig. 4A). Between about $12^{\circ} 30^{\prime}$ and $14^{\circ} 30^{\prime}$ an incoming sediment section 2 to $3 \mathrm{~km}$ thick is deformed into a series of westward-dipping reflectors interpreted as eastwardverging thrusts structurally overlying a thin underthrust sequence (Westbrook et al., this volume). North of $15^{\circ}$ the toe of the Barbados Ridge complex is characterized by an arcward-thickening wedge of acoustically irresolvable material that overlies a tabular acoustically layered sequence (Fig. 4B). The incoming sediment thickness is about $1 \mathrm{~km}$ in this area. West of the deformation front, the acousticaly layered sequence can be traced for tens of kilometers beneath the Barbados Ridge complex (Westbrook et al., 1982).

Although much deformation is concentrated at the eastern margin of the Barbados Ridge complex, additional shortening occurs throughout the accretionary complex and at its contact with the forearc basins, the Tobago Trough and Lesser Antilles Basin (Figs. 1 and 2). Both the arching and uplift of the Quaternary coral cap of Barbados Island (Speed and Larue, 1982) and the seismically documented folding and faulting of surface sediments (Mascle et al., in press; Biju-Duval et al., 1982 ) attest to the youth of the deformation.

The geologic history of the Lesser Antilles (Bouysse et al., this volume) and the evolution of Barbados Island (Speed and Larue, 1982) provide insights on the early history of the Barbados Ridge complex. Prior to middle Eocene a thick clastic sequence (Scotland Formation of Barbados) accumulated east of the Lesser Antilles island arc. From middle Eocene to early Miocene, underthrusting of the Atlantic ocean crust is suggested by the nearly continuous activity of volcanoes in the Lesser Antilles islands and deformation of Eocene and Oligocene deep-sea deposits on Barbados Island. The present phase of arc magmatism began in the late Miocene during which time the Orinoco and Amazon rivers supplied copious sediment to the forearc, apparently causing its rapid accretionary growth.

\section{DRILLING RESULTS}

\section{Lithology}

The 78A drilling program involved an assemblage of six holes at three sites. Two sites are 3 and $1.5 \mathrm{~km}$ landward of the deformation front, and a third site is $1.5 \mathrm{~km}$ seaward of the deformation front (Fig. 3). Lithologies recovered on Leg $78 \mathrm{~A}$ are hemipelagic and pelagic deposits (Fig. 6), with sedimentation rates averaging $\sim 25$ $\mathrm{m} / \mathrm{Ma}$ (Wright, this volume). At all three sites the shallowest major lithologic unit is Quaternary and Pliocene and consists of calcareous sediment: marly nannofossil ooze, marly foraminifer ooze, and nannofossil mud. This unit extends to the surface at Sites 541 and 542 but is covered by $10 \mathrm{~m}$ Holocene mud at Site 543 . The lower contact of the calcareous unit ranges from the upper lower Pliocene to the Miocene/Pliocene boundary. Hemipelagic, locally vitric mud, barren of calcareous detritus, constitutes the second major unit encountered in each of the Leg 78A sites. This lithology extends down section to about the middle Miocene, where it is underlain by radiolarian clay at Sites 541 and 543 . At the oceanic reference site (Site 543) radiolarian clay-claystone persists to the lower Eocene; zeolitic clay-claystone is present from 322 to $379 \mathrm{~m}$ sub-bottom and overlies a basal calcareous, ferruginous, Maestrichtian to Campanian claystone that contacts basalt at $409 \mathrm{~m}$ sub-bottom.

The transition from hemipelagic clay to carbonaterich sediments during the late Miocene to early Pliocene suggests that the Leg 78A sites passed upward through the carbonate compensation depth (CCD) at this time (Hemleben and Auras, this volume), probably in response to a global depression of this surface (Berger, 1977). Site 543 crossed the CCD in the early Pliocene, significantly later than the late Miocene passage of Sites 541 and 542 through this boundary. This variation is probably the result of the accretion of the sections at Sites 541 and 542 from shallower positions on the Tiburon Rise. The earlier passage of Sites 541 and 542 through the CCD probably does not reflect their uplift at the deformation front, as these sites show a similar rather than sequential age of CCD transition.

The similar lithologic sequences at the Leg 78A sites also exhibit corresponding suites of clay minerals (Pudsey; and Latouche and Maillet, this volume). Of particular structural significance is the enrichment of smectite in the Miocene hemipelagic mud at all sites. The dominance of smectite decreases in the Pliocene, and in the Pleistocene illite is the most abundant clay mineral. Smectite is also the predominant clay mineral in relatively rapidly deposited lower Eocene pelagic claystones at Site 543.

\section{Structural Geology}

One of the most important results of Leg 78A is the direct observation of thrust or reverse faults in a modern subduction zone. We penetrated three significant faults 
A
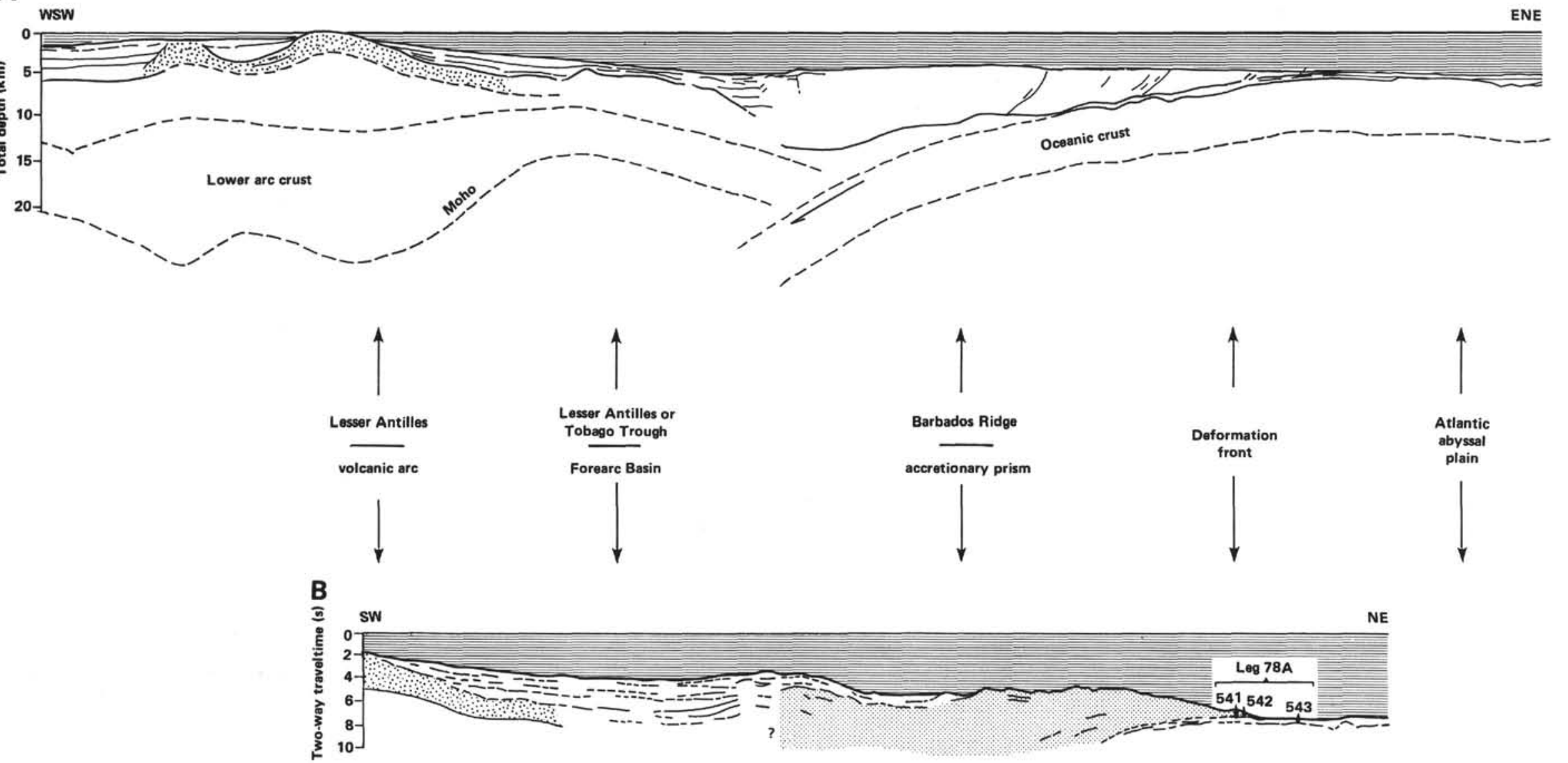

NE

$25 \mathrm{~cm}$

Figure 2. Cross sections from the Atlantic abyssal plain to the Lesser Antilles volcanic arc. A. Taken from Shell Line 2114 (Speed et al., in press). B. CEPM Line A3-A2 (after Mascle et al., in press). 


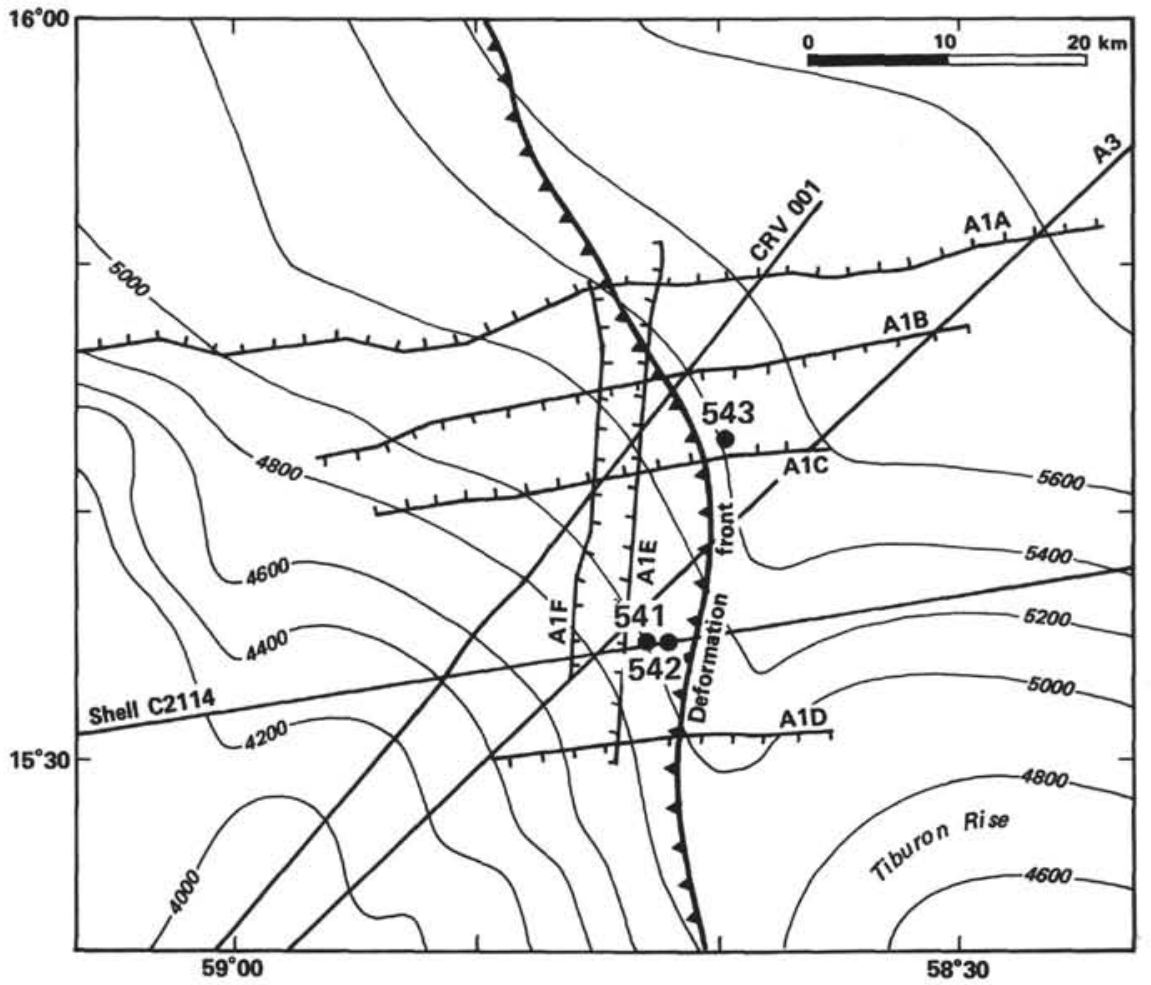

Figure 3. Detailed site location map (box, Fig. 1). Note seismic Lines A3 and Shell C2114 that are the basis for cross sections in Figure 2.

\section{A}
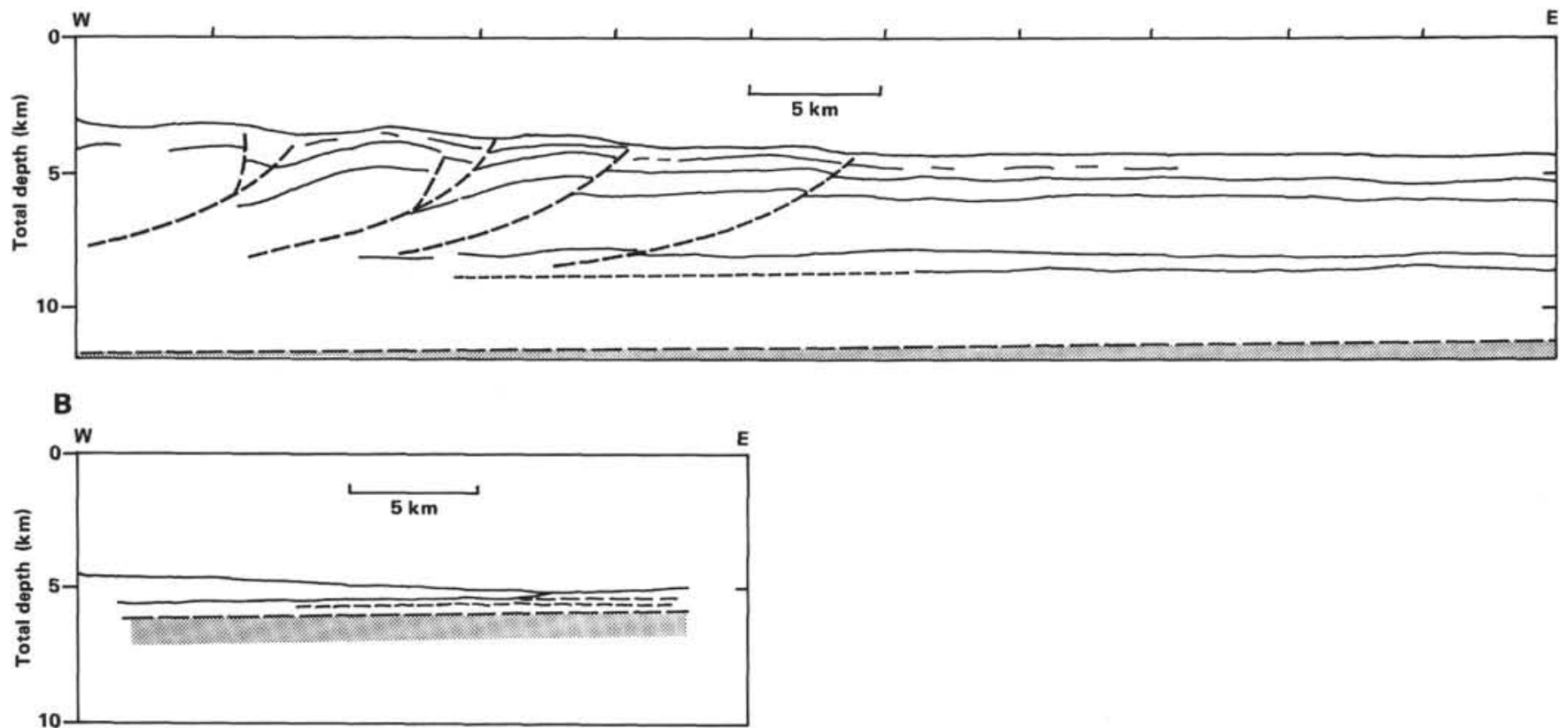

Figure 4. Comparative cross section from A. an area, south of $12^{\circ} 30^{\prime} \mathrm{W}$, where incoming sediment thickness is several kilometers and from B. the Leg 78A area. Seismically resolvable fold-thrust packages are apparent to the south (A), whereas in the Leg 78A area the thinner thrust sheets are not resolvable at the scale of this diagram (see Fig. 14 for details). 


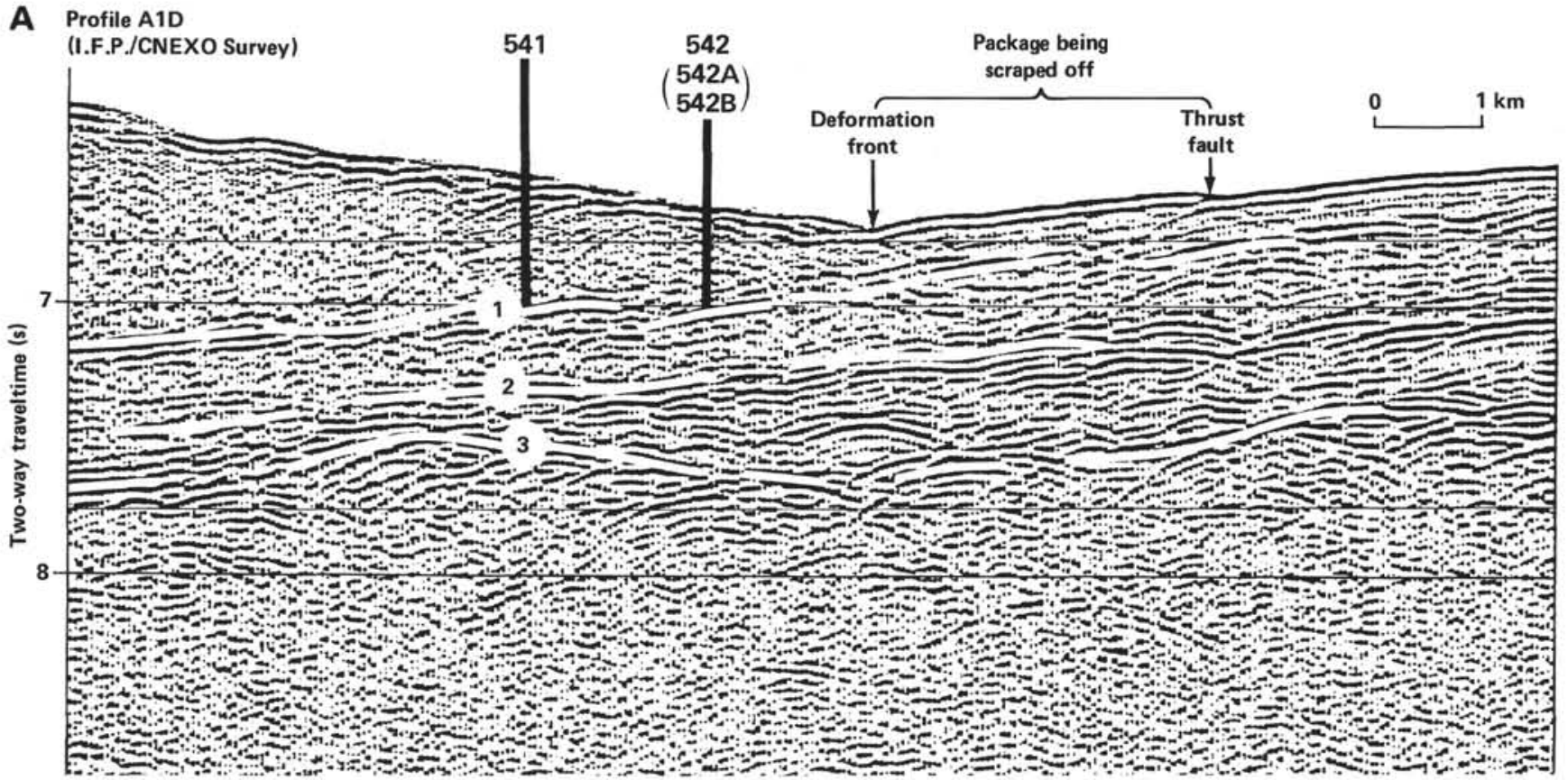

B Profile A1C

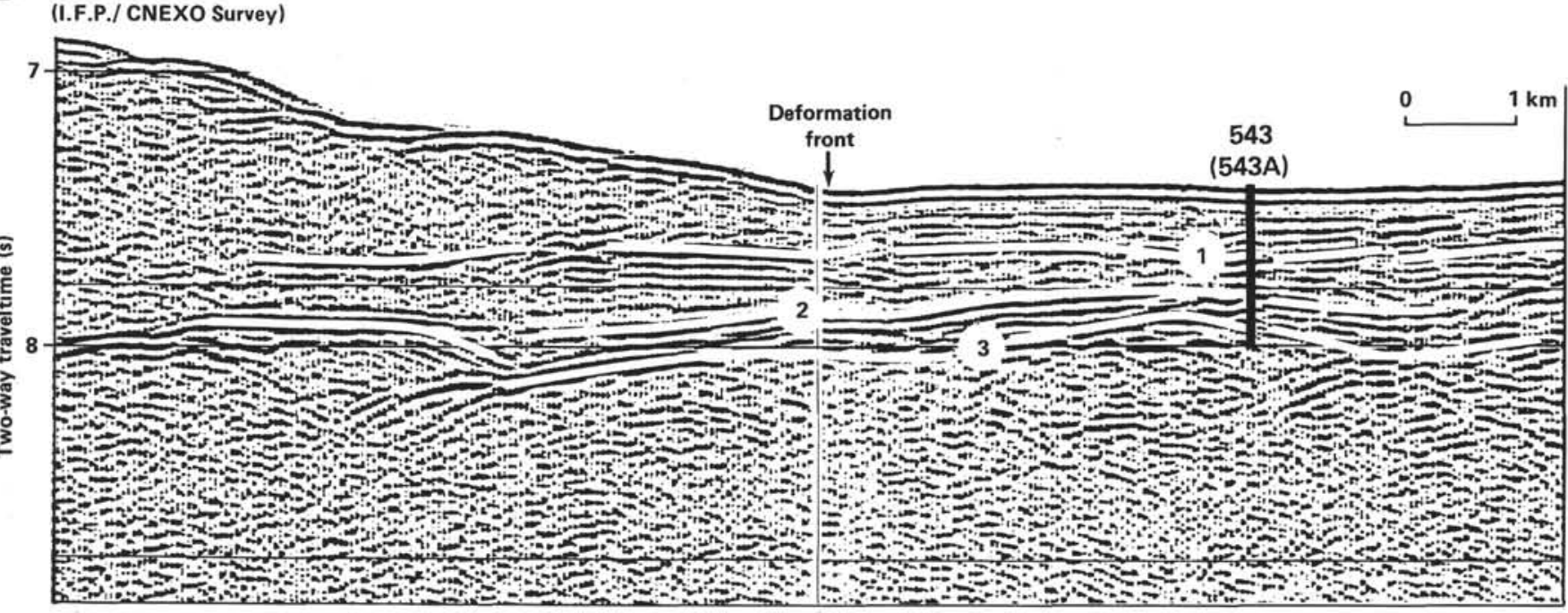

Figure 5. A and B. Seismic profiles along which drilling sites are located (Ngokwey et al., this volume). See Figure 3 for location. West of the deformation front, Reflector 1 separates the discontinuously reflective seismic unit from the acoustically layered unit below; this surface is interpreted as a décollement; the equivalent stratigraphic level has also been projected seaward as Reflector 1 . Reflector 3 marks the top of the oceanic crust. Reflector 2 separates two parts of the acoustically layered unit: an upper tabular sequence and a lower portion of variable thickness. On Line A1D the thrust fault $3 \mathrm{~km}$ east of the deformation front appears to sole out near Reflector 1 and define the eastern limit of the sediment package presently being scraped off.

at Site 541 and two faults at Site 542 (Figs. 6, 7). Specification of the location and throw of these faults was possible because of the excellent biostratigraphic resolution of nannofossils within the relatively slowly accumulated sequence (Bergen, this volume). The deformation zones occurring at the base of both Sites 541 and 542 constitute another significant structural feature discovered on Leg 78A. The deformation zone at the base of Site 541 appears to occur at the top of the acoustically layered sequence. Material recovered from this zone locally resembles fault gouge (Cowan et al., this volume). A thrust or reverse fault is associated with the deforma- tion zone at the base of Hole 542A, although the bottom of this hole lies just above the acoustically layered sequence.

Bedding dips of up to about $45^{\circ}$ occur below $100 \mathrm{~m}$ sub-bottom at both Sites 541 and 542, although the mean bedding dip at these sites is less than $20^{\circ}$ (see Cowan et al., this volume). A change in small-scale structural fabrics or patterns of bedding dips is commonly associated with the location of the biostratigraphically defined thrust or reverse faults (Cowan et al., this volume). A transition from foliated, stratally disrupted smectitic mudstone to essentially undeformed marl occurs across 

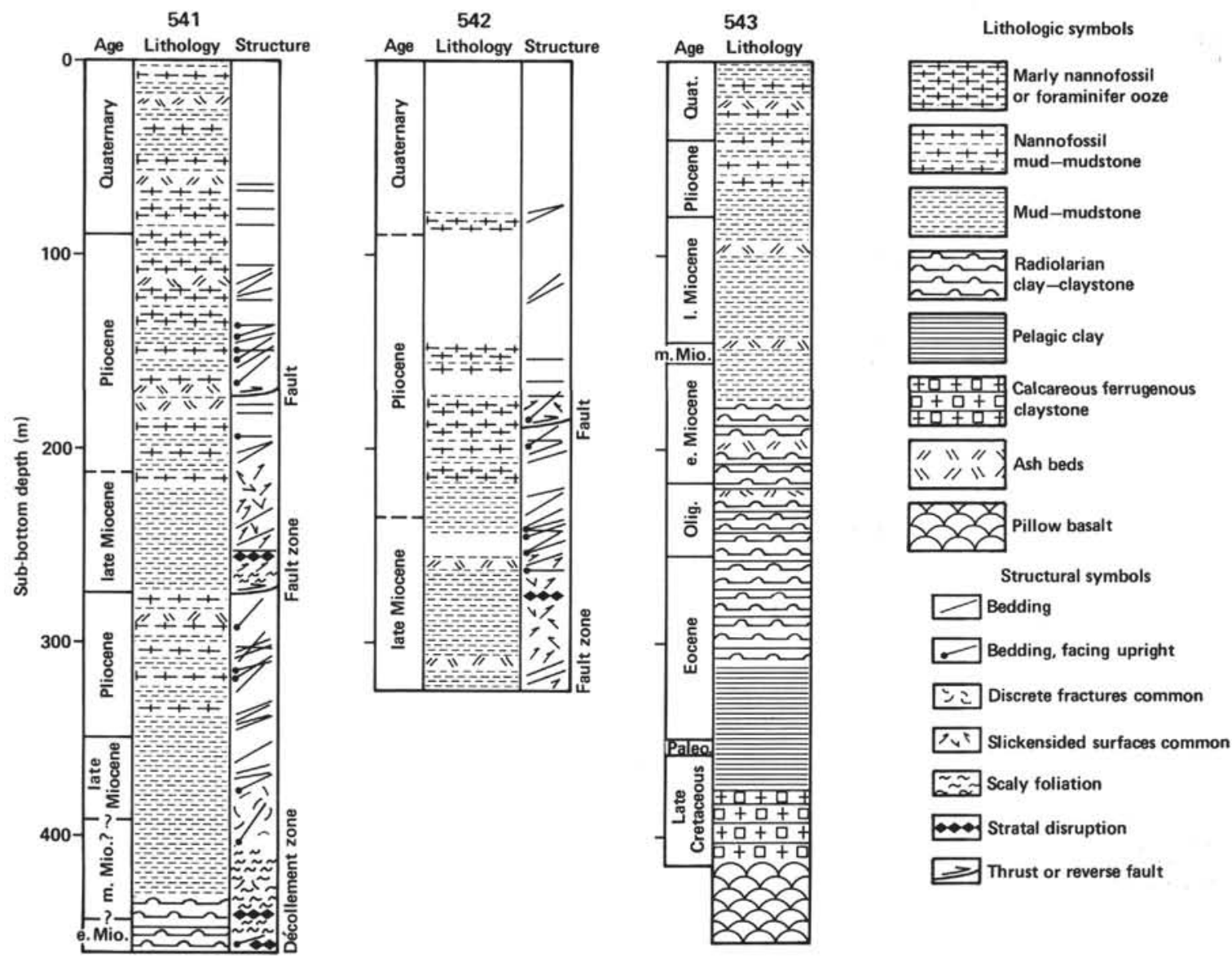

Figure 6. Lithostratigraphy and structural geology of the cores at Sites 541, 542, and 543.

a thrust or reverse fault at $276 \mathrm{~m}$ at Site 541. Faults with the largest throw are more likely to occur in the middle and upper Miocene smectitic mudstone.

Paleomagnetic studies of cores from Sites 541 and 542 allow reconstruction of the orientation of bedding planes (Wilson, this volume). Eight oriented bedding planes from Site 541 show westerly to southerly down-dip directions. Nine oriented bedding planes from Site 542 indicate predominantly southerly to easterly down-dip directions. Although defying simple interpretation, these paleomagnetically determined dip directions have been used to constrain our cross section.

A significant hiatus occurs in the deformation zone at the base of Site 541 , as compared to the sequence at Site 543. At the latter, the distance from the first downhole occurrence of radiolarians to the Stichocorys delmontensis Zone is $49 \mathrm{~m}$. whereas at Site 541 this same interval is only $28 \mathrm{~m}$; it has one apparently thinned zone, and one zone is missing (Fig. 8). This hiatus could be purely stratigraphic; however, its magnitude and its presence in an interval of complex deformation argues for a tectonic origin. The deformed, poorly consolidated sediment probably contributed to the hole-stability problems and poor recovery at the base of Site 541 (see Site 541 report, this volume).

\section{Discussion: Offscraping and Underthrusting}

Overall, the sediment types and vertical sequences encountered, and the paleoenvironments inferred arcward of the deformation front at Sites 541 and 542 are very similar to those sampled and inferred at the reference site (Site 543), arguing for offscraping of strata sampled at the former sites. At Sites 541 and 543, each drilled section progresses from lower Miocene radiolarian mud to barren mud in the middle Miocene, then to calcareous mud or ooze in the upper Miocene or Pliocene (Fig. 6). The latter transition is recorded also at Site 542. At all sites Pleistocene and Pliocene deposits accumulated between the lysocline and CCD; however, Miocene sediments were deposited principally below the CCD. Minor differences between the three sites in paleobathymetry and apparent sedimentation rates of post-Miocene deposits probably reflect variations in the water depth of the incoming oceanic plate, and structural modifications during offscraping (discussion follows).

Thrust or reverse faulting and relatively steep dips within the acoustically discontinuous unit (offscraped deposits) suggest a disharmonic contact (décollement) with the underlying acoustically layered unit. This décollement probably lies along a well-defined reflector separating these two acoustic units. Correlation of seismic reflection Profile A1D and drilling results suggests that Site 541 penetrated about $20 \mathrm{~m}$ into the top of the acoustically layered sequence. The radiolarian zone at the base of Site 541 (Stichocorys delmontensis) occurs just below a sharp change in lithology and physical properties at Site 543 (Fig. 9); we believe the décollement ultimately develops at this change in physical properties. 


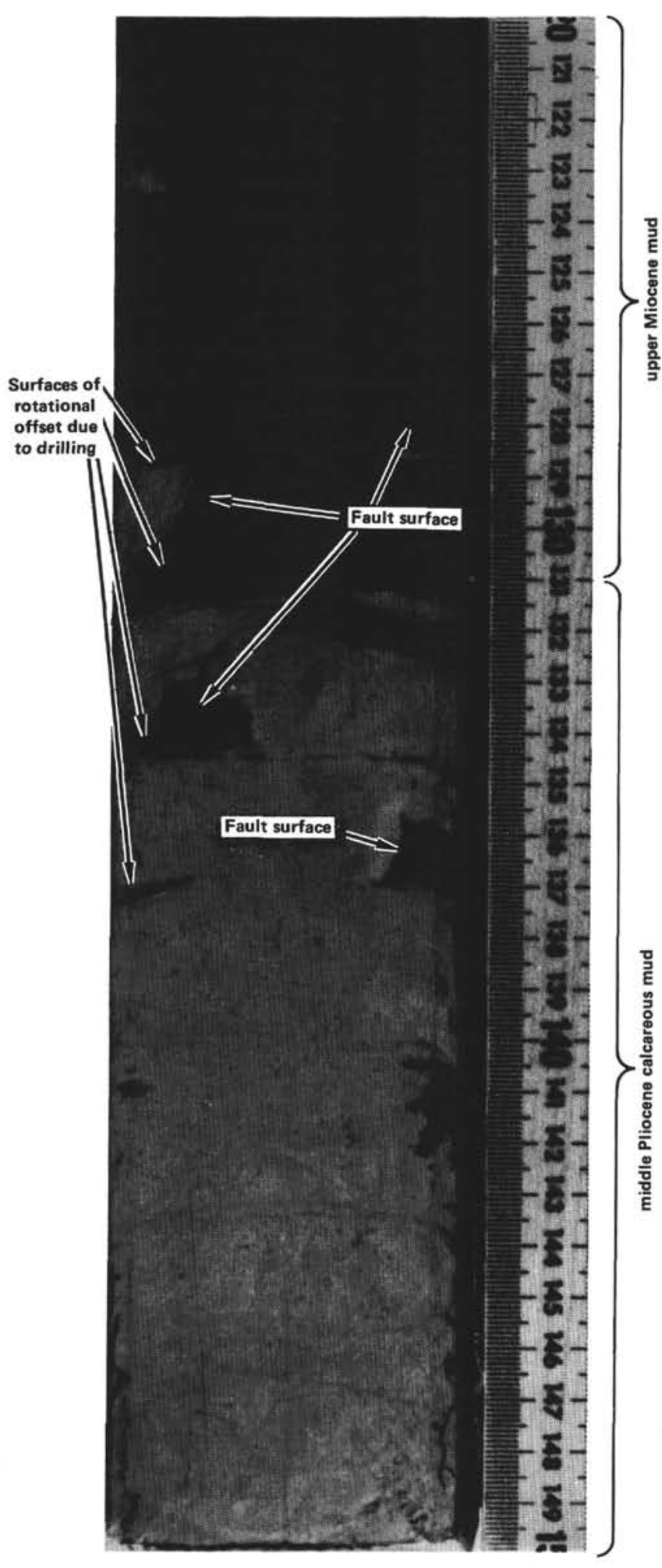

Figure 7. Photograph of Core 30, Section 6 showing thrust or reverse fault at $276 \mathrm{~m}$ sub-bottom depth at Site 541. Darker sediment (mostly above $131 \mathrm{~cm}$ ) is upper Miocene mud. Lighter sediment (mostly below $131 \mathrm{~cm}$ ) is middle Pliocene calcareous mud. Fault contact has been rotated by drilling and folded prior to drilling.

Moreover, it is noteworthy that the reflector separating the discontinuously reflective unit and the acoustically layered unit can be followed to Site 543 where it is at about $170 \mathrm{~m}$, near the change in physical properties at

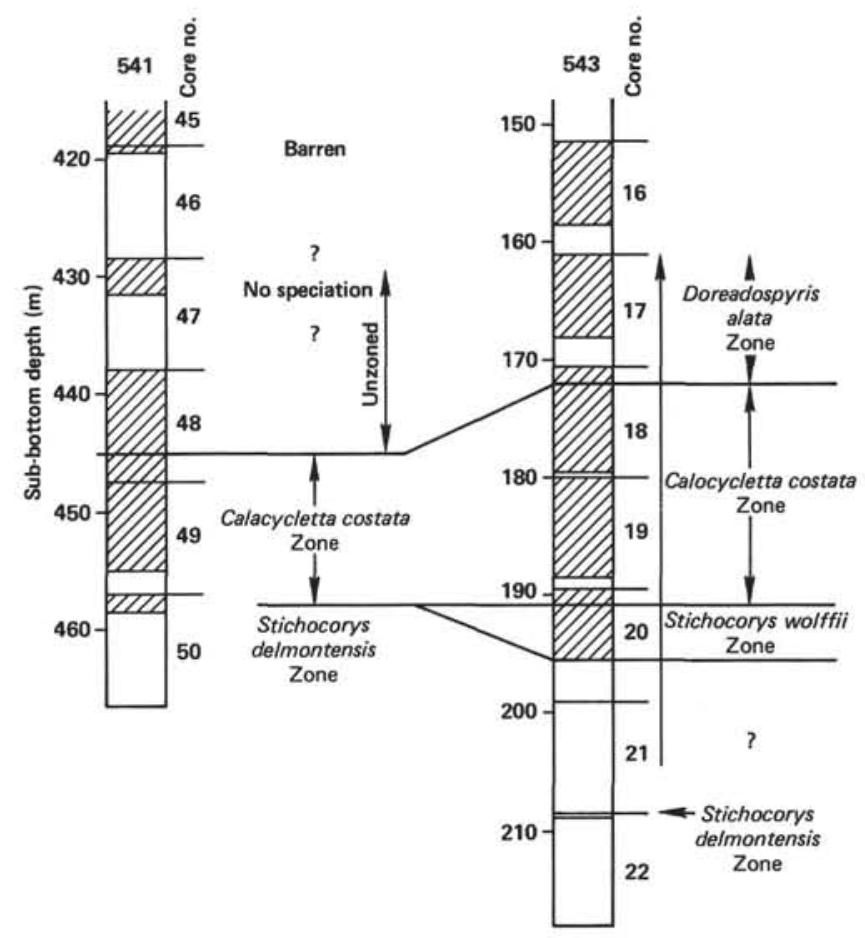

Figure 8. Comparison of radiolarian zonation between Sites 541 and 543. Note missing and thinned zones at Site 541.

that site (Fig. 9). We therefore believe that the underthrust, acoustically layered deposits are equivalent to the section below about $200 \mathrm{~m}$ at Site 543, and range from lower Miocene to Eocene radiolarian clay down through Eocene-Paleocene(?) pelagic clays to a basal Upper Cretaceous, ferruginous, calcareous claystone. In a seismic record adjacent to the Leg $78 \mathrm{~A}$ area, this acoustically layered sequence can be traced and is presumably underthrust at least $72 \mathrm{~km}$ landward of the deformation front (Westbrook et al., this volume).

\section{Fluid Pressure, Temperature, and Physical Property Data}

After attempting to penetrate through the basal deformation zone at both Sites 541 and 542 using conventional techniques, at Site 542 we emplaced $60 \mathrm{~m}$ of drillin casing in this interval of fractured and foliated material (Fig. 10). The casing became stuck in the deformation zone, as planned; however, owing to a technical failure we were unable to release the drill pipe from the casing and continue drilling to greater depth. As the casing became stuck it packed-off, sealing the external surface of the casing against the hole. The packing-off presumably occurred as a result of collapse of the unstable hole and settling of any suspended drilling debris around the casing. Therefore, the attached drill pipe provided a closed system for monitoring fluid pressure in the basal deformation zone below the level of packing-off.

Immediately upon sticking of the drill stem an excess pressure of 300 to 350 psi was measured on the rig floor (see Site 542 report, this volume). During attempts to release the drill string we pumped into the deformation zone at a rate of 480 gallons/min. with no apparent resistance, which suggests that the deformation zone is of 


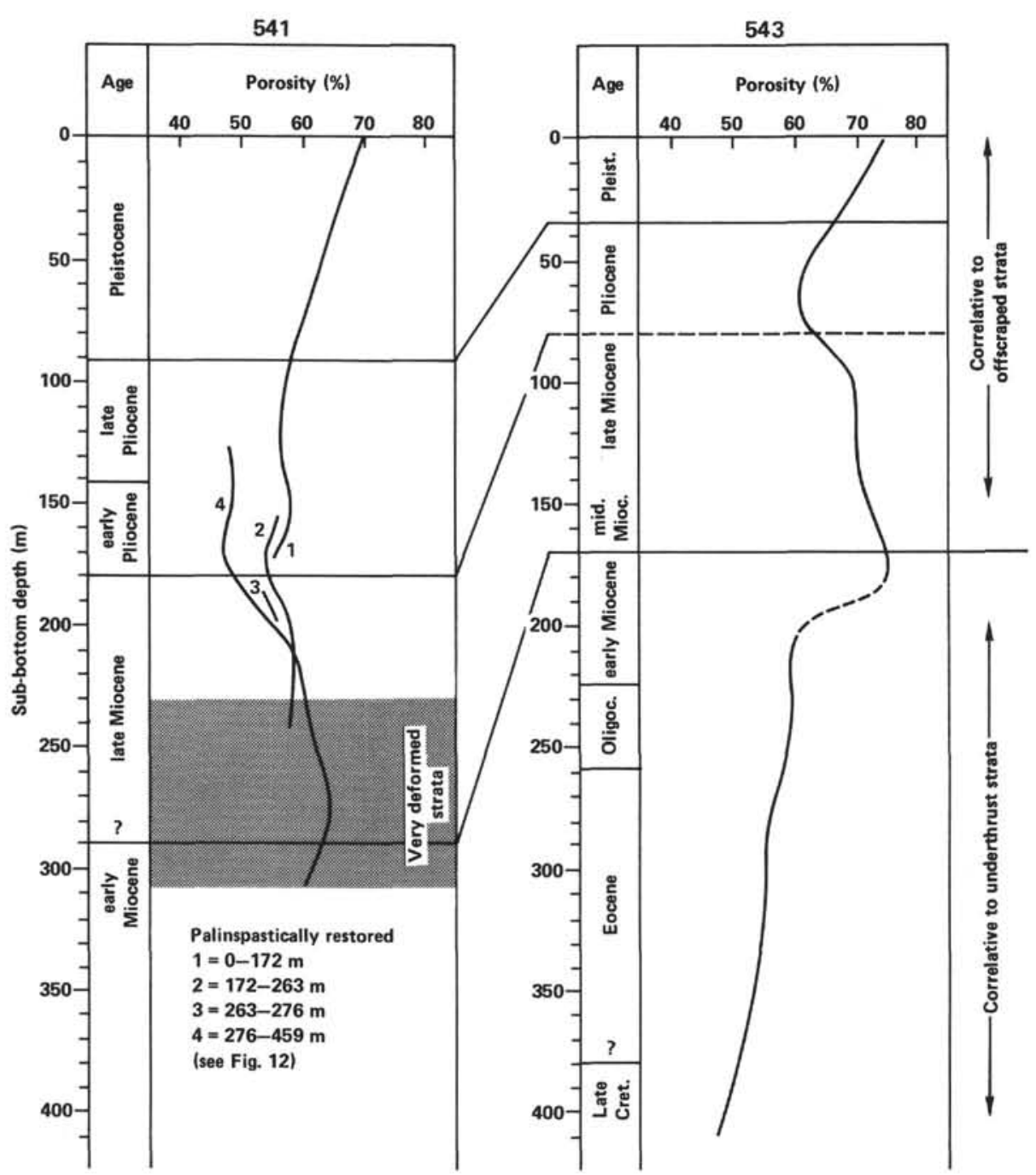

Figure 9. Comparison of physical properties and lithology for Sites 541 and 543 (Site 541 palinspastically restored).

high permeability, probably because of fractures. The observed pressure of 300 to $350 \mathrm{psi}\left(21.0-24.5 \mathrm{~kg} / \mathrm{cm}^{2}\right.$ or $2.06-2.4 \mathrm{MPa}$ ) is approximately equivalent to the integrated buoyant bulk density measured in the overlying sediment column (Marlow et al., this volume). Hence, the fluid pressure in the deformation zone balances the superincumbent lithostatic load, causing the effective stress in the deformation zone to be negligible (Davis, this volume).

The direct measurement of high fluid pressure in the deformation zone at Site 542 provides a means of explaining perplexing temperature data. At Site 541, temperature logs taken after drilling was completed reveal temperatures ranging from 14 to $16^{\circ} \mathrm{C}$ from 49 to $166 \mathrm{~m}$ sub-bottom. The temperatures are excessive for shallow depths (Davis and Hussong, this volume) and probably are not from a conductive heat-flow gradient. Rather we believe that these high temperatures result from the upward flow of warm water from the overpressured deformation zone penetrated at the base of Site 541. Somewhat abnormal temperatures were observed at Site 542 and also may be explained by upward flow of warm water (Davis and Hussong, this volume).
Interstitial water chemistry argues against large-scale vertical advection of fluids through the drilled sediment at the scale of sampling $\left(350-\mathrm{cm}^{3}\right.$ samples taken about every $40 \mathrm{~m}$ downhole-Gieskes, this volume). Fluid pressures may be abnormal throughout the sediment column, however, the low permeability of the hemipelagic to pelagic sediment may restrict fluid movement; any fluid movement is probably not uniformly distributed through sediment pores but must be in restricted zones. The basal deformation zone (décollement) at Site 541 is probably one such fluid conduit. The location of the measured high fluid pressure at the base of Site 542 appears to be in a thrust zone that roots in the décollement. Significant fluid movement probably occurs in the décollement and in active faults splaying off it but does not permeate the offscraped sediment prism.

How physical properties subtly control structural style is illustrated by the porosity variations at Site 543 (Fig. 9). Porosity at Site 543 shows a systematic decreasefrom about 70 to $50 \%$-with depth, except in an interval from about 100 to $200 \mathrm{~m}$ sub-bottom (Marlow et al., this volume). This Miocene, smectitic mud-rich interval includes porosities up to $75 \%$, significantly higher than 


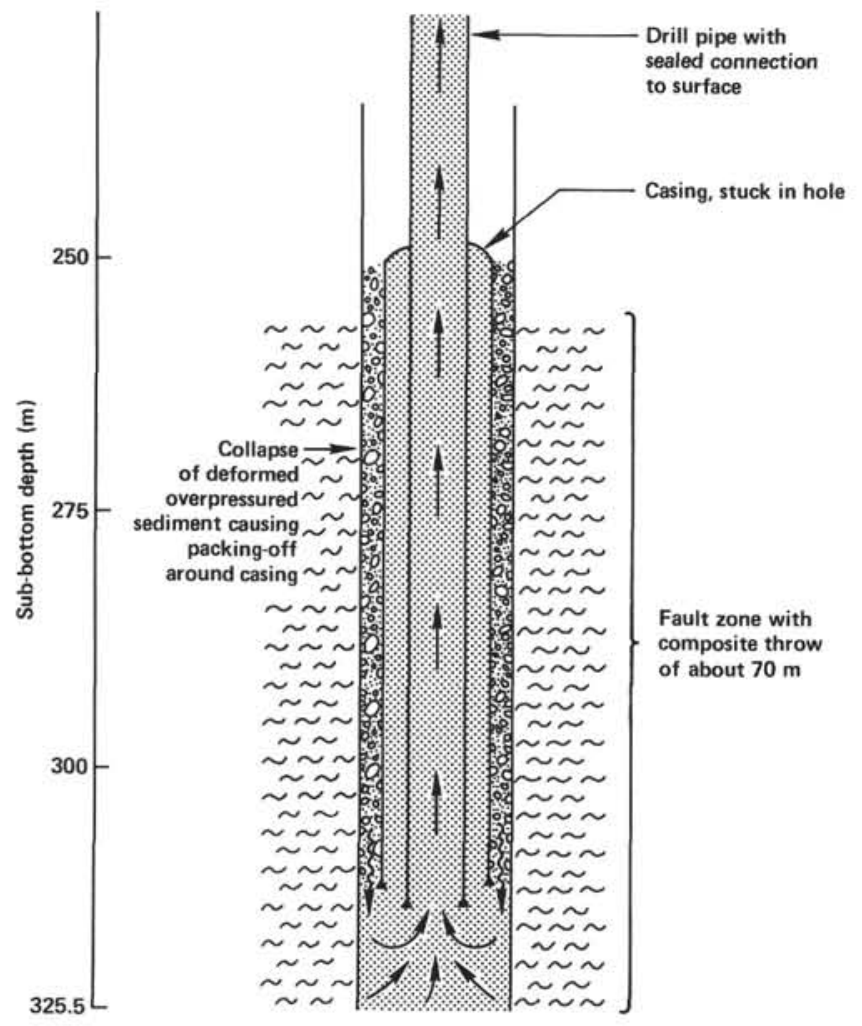

Figure 10. Schematic of inadvertent packer experiment.

the $60 \%$ porosities in the immediately overlying marls. In fact, the highest porosity in the smectitic muds occurs at about $180 \mathrm{~m}$ sub-bottom near where the décollement ultimately develops. At $200 \mathrm{~m}$ sub-bottom a sharp decrease in porosity is matched with an increase in vane shear strength (Marlow et al., this volume). Thus the elevated porosity and the relatively low strength of the smectite-rich mud probably explains why the largerscale thrust or reverse faults are more likely to form in this lithology(Fig. 6). Notably, the enhanced porosity of the smectitic mud relative to the overlying marl is maintained even after deformation at Site 541 (Fig. 9; Marlow et al., this volume).

The physical property data provide a possible measure of volume reduction during deformation. The upper $200 \mathrm{~m}$ at Site 543 is the equivalent in age and lithology to all deposits penetrated at Sites 541 and 542 . The average of porosity measurements in the upper $200 \mathrm{~m}$ at Site 543 is $68 \%$, whereas the average of all porosity measurements at Sites 541 and 542 is $58 \%$. Assuming that porosities at both sites were originally the same, this $10 \%$ difference in porosity is equivalent to about a $25 \%$ reduction in total volume during about $1.5 \mathrm{Ma}$ of deformation.

\section{INTERPRETATION OF STRUCTURAL GEOMETRY}

\section{Site Survey Data and Structural Geometry}

The site survey and related geophysical data consist of seismic reflection lines, a multibeam bathymetric (Seabeam) survey, and a long-range side-scan sonar (GLORIA) survey. The seismic reflection data are especially useful in defining the overall geometry of the units penetrated during drilling (see Westbrook et al., this volume). As noted earlier, the disharmony between the thrust-faulted, offscraped unit and the subjacent acoustically layered sequence suggests the presence of a décollement zone in the basal section at Site 541. This décollement is manifested seismically as the boundary between the discontinuously reflective and acoustically layered seismic units. This boundary dips 2 to $3^{\circ}$ to the west and can be traced approximately $30 \mathrm{~km}$ beyond the deformation front on seismic lines in the Leg 78A area. Just to the north on Discovery 109 Line 17, this décollement can be traced $72 \mathrm{~km}$ westward of the deformation front toward the Lesser Antilles islands. The décollement appears unbroken to $45 \mathrm{~km}$ westward of the deformation front; arcward of this point the décollement seems to be cut by major faults and may step down through the subjacent acoustically layered sequence causing apparent underplating (Westbrook and Smith, 1983). Our drilling results indicate that the underthrust acoustically layered sequence is composed of lower Miocene to Campanian pelagic sediments. Middle(?) to upper Miocene through Quaternary hemipelagic sediments constitute the structurally overlying, discontinuously reflective unit.

The discontinuously reflective seismic unit forms a wedge that thickens to the west. Continuous reflections in this unit do not exceed $5 \mathrm{~km}$ in length at the resolution of the seismic techniques employed (Westbrook et al., this volume). The minimal impedance contrasts in this unit contribute to its lack of reflections (Marlow et al., this volume). The stratigraphic inversions documented at Sites 541 and 542 may in part correspond to some discontinuous reflections on seismic Line A1D (Fig. 5A). A nearby high-resolution seismic profile suggests westward-dipping beds (also shown by the paleomagnetic data at Site 541) and eastward-verging thrusts.

Both the Seabeam and GLORIA surveys (Fontas et al., this volume; Belderson et al., this volume) reveal linear topographic highs that may reflect the surface expression of thrust faults and folds. The deformation front of the Barbados Ridge complex is sinuous but well defined by both Seabeam and GLORIA data. The lowermost slope of this complex is gentle $\left(3-7^{\circ}\right)$, but with some steep eastward facing slope breaks of up to $12^{\circ}$. Very small ridges and troughs are observed on the sonographs, parallel to the deformation front (Belderson et al., this volume). The Seabeam map shows north-south highs with relatively steep eastward-facing slopes that may represent thrust scarps (Fontas et al., this volume). the linear topographic features landward of the deformation front have the following estimated dimensions: wave length $-0.5 \mathrm{~km}$ (GLORIA), $1.5 \mathrm{~km}$ (Seabeam); height-10 m (GLORIA), 25-50 m (Seabeam); length$12 \mathrm{~km}$ (GLORIA), $1-5 \mathrm{~km}$ (Seabeam). The differing dimensions apparently reflect the variable resolution of GLORIA and Seabeam. In both cases the linear features disappear upslope, probably the result of blanketing by slope sediments.

The fine-scale surface morphology of the Leg 78A area contrasts with the broad linear highs and lows (large thrusts and related folds) of the area south of $12^{\circ} 30^{\prime}$ 
(Biju-Duval et al., 1982; Figs, 4 and 11). However, the morphology of the Leg $78 \mathrm{~A}$ area is comparable with that at about $13^{\circ} \mathrm{N}$, where westward-dipping reflectors are interpreted as low-angle thrusts (Westbrook et al., this volume). Clearly, the separation of the surface traces of the thrust faults and related folds is directly proportional to the thickness of sediment above the décollement (Fig. 11).

The site survey data reveal several significant influences of the Tiburon Rise in the Leg 78A area. As mentioned earlier, seismic data indicate that the Tiburon Rise is covered by a relatively thin sediment blanket compared to areas to the north and south. Moreover, where the Tiburon Rise intersects the deformation front, the latter changes to an east-west configuration with probable left-lateral faulting. The small-scale linear topographic features resolved on the Seabeam and GLORIA data also adopt this east-west trend. In the Leg 78A area the predominantly north-south linear topographic features are crosscut by approximately east-west trends that may reflect lateral faulting resulting from the collision of the Tiburon Rise.

\section{Thickness Restoration of Section at Sites 541 and 542}

The excellent biostratigraphic resolution at Sites 541 and 542 allows documentation of the throws of the faults penetrated during drilling (faults and potential faults are numbered 1-7 in Fig. 12). Thus we can compare the thickness of the restored section to the thickness of the incoming sediment available for offscraping.

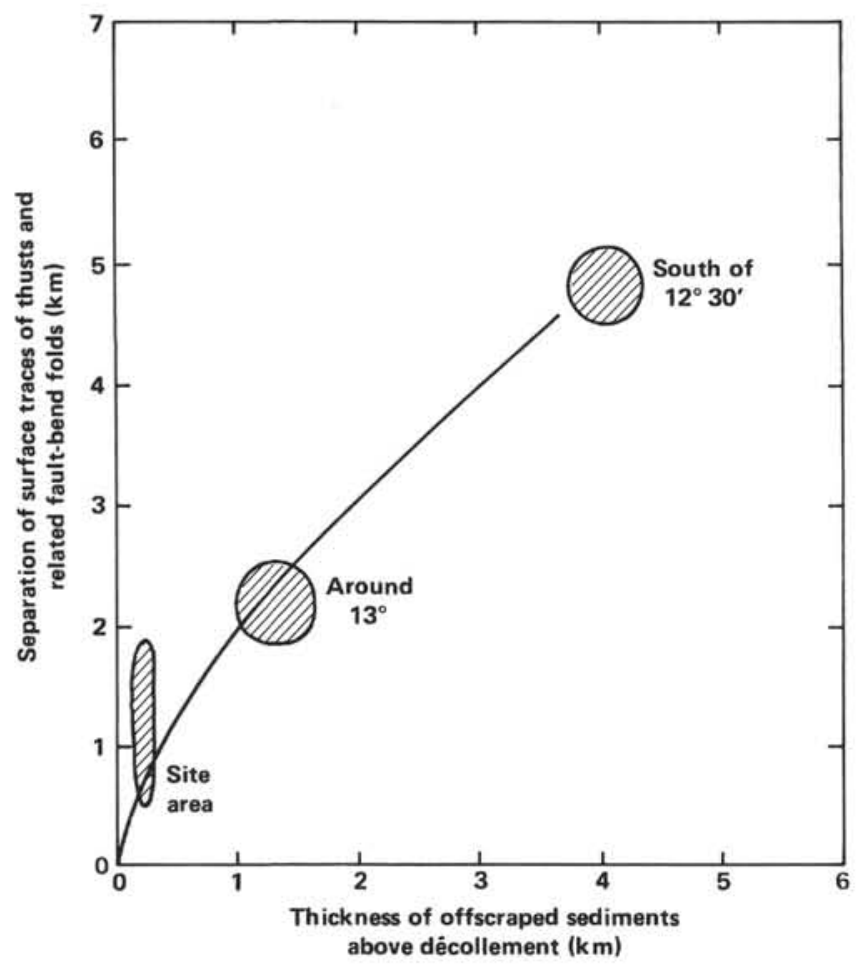

Figure 11. Plot of surface traces of thrusts and related fault-bend folds versus thickness of incoming sediments on the Atlantic abyssal plain.
At Site 541, matching of displaced nannofossil zones (Bergen, this volume) reveals a total throw of $156 \mathrm{~m}$ on four faults (Fig. 12). Faults 3 and 4 at 263 and $276 \mathrm{~m}$ sub-bottom show a cumulative throw of $130 \mathrm{~m}$ and probably represent a major imbrication within the offscraped sequence. Accordingly, we separate the section into two major tectonic slices, with the fault at $276 \mathrm{~m}$ sub-bottom bounding slice 2 , above, and slice 1 , below. Fault 2 at $172 \mathrm{~m}$ sub-bottom involves a throw of $20 \mathrm{~m}$ and is probably a minor imbrication within slice 2 . A minor repetition at $72 \mathrm{~m}$ sub-bottom may be a slump.

Faults with a total throw of about $100 \mathrm{~m}$ are documented within the cored section at Site 542. A fault at $190 \mathrm{~m}$ sub-bottom shows a throw of $32 \mathrm{~m}$ and probably is an internal imbrication within tectonic slice 1 , which we extend from Site 541 to Site 542 . The basal $85 \mathrm{~m}$ cored at Site 542 include sediments of only nannofossil Zone CN9a, but patterns of fossil recurrence suggest that one and perhaps three repetitions occur within this zone (Bergen, this volume). Moreover, the expected thickness of this zone in an undeformed section would be a maximum of $15 \mathrm{~m}$ given the sedimentation rate in equivalent deposits at Site 543 (Wright, this volume), and a zone duration of about 1.4 Ma (Barron et al., 1981). Therefore we estimate a total throw of about $70 \mathrm{~m}$ within the basal and highly disrupted portion of Site 542 .

The original thickness of the incoming sediment section can be restored by unfaulting, untilting, and correction for the porosity reduction in sections penetrated at Sites 541 and 542 (Fig. 13). Note that the restoration of fault throws accounts for any folding, small-scale deformation, and minor faulting occurring in the vertical section between the repeated nannofossil zones. The lower boundary of the offscraped deposits probably occurs in a zone of low recovery and stratigraphic hiatuses from 420 to $456 \mathrm{~m}$ sub-bottom at Site 541. For purposes of thickness reconstruction we somewhat arbitrarily selected the midpoint at $438 \mathrm{~m}$ sub-bottom as this boundary. We estimate that about $50 \mathrm{~m}$ of slope sediments have accumulated since Site 541 began to be uplifted at the deformation front. Thus the total thickness of offscraped sediment is presently $388 \mathrm{~m}$. After correcting for fault displacements $(-156 \mathrm{~m})$ and measured tilts $(-27 \mathrm{~m})$, $205 \mathrm{~m}$ of section remain. During deformation the volume of the offscraped section decreased $25 \%$, as estimated from changes in porosity. The proportions of vertical and horizontal shortening necessary to achieve this volume reduction is unknown. Assuming uniform volume decrease both vertically and horizontally, the unfaulted, tilt-corrected, re-inflated section totals $216 \mathrm{~m}$. This figure agrees well with the approximately $200 \mathrm{~m}$ of section to which the offscraped deposits correlate at Site 543 . Moreover, $200 \mathrm{~m}$ is the approximate, seismically determined thickness of sediment presently being scraped off seaward of Site 541 along seismic Line A1D (Fig. 5A). At Site 542 a similar but less well-constrained reconstructive exercise suggests an original thickness of about $202 \mathrm{~m}$ for a section that extends nearly, but not completely, to the décollement. Errors in the thickness reconstructions probably do not exceed $20 \%$ of the final 


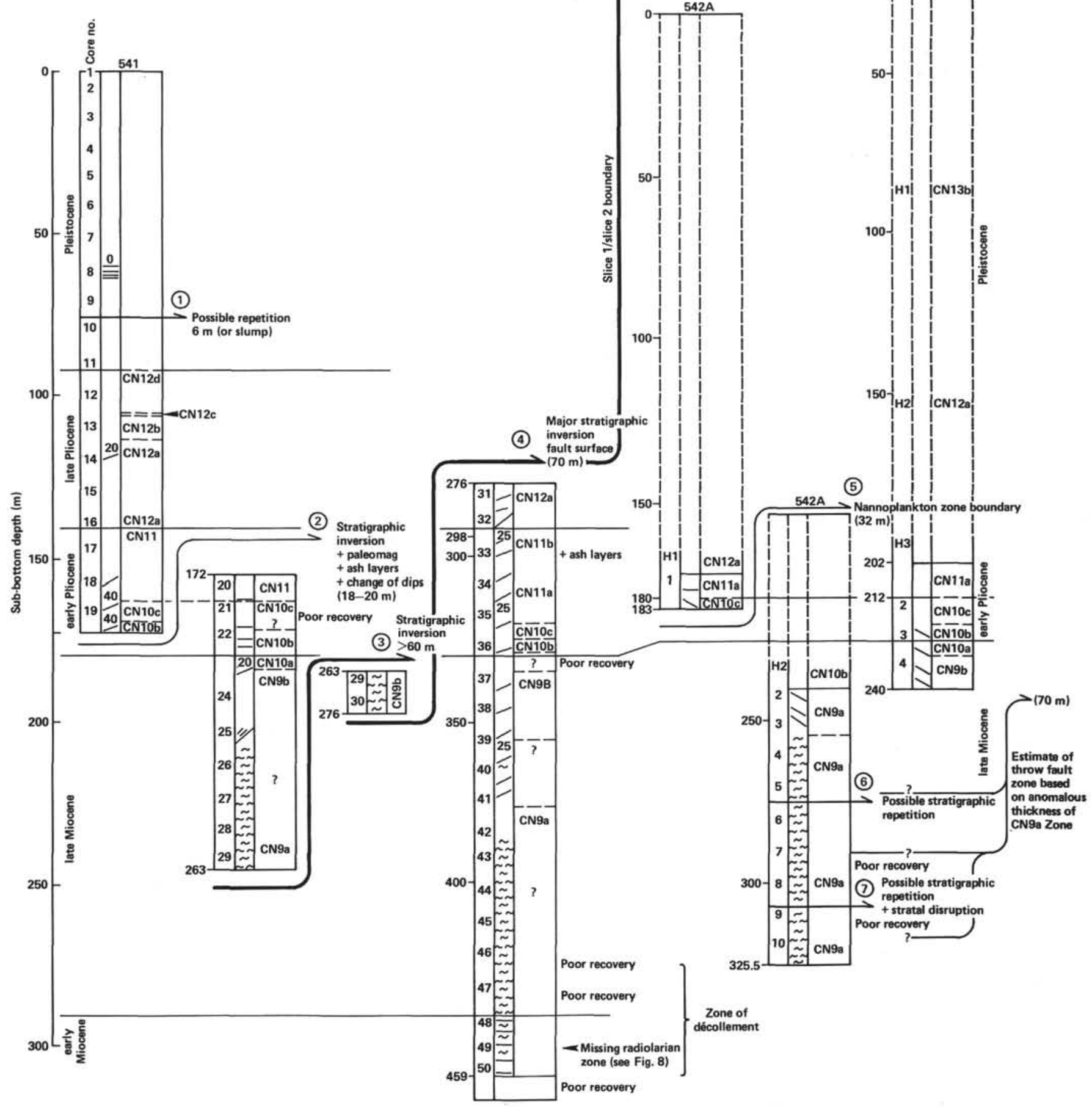

Figure 12. Palinspastic restoration of fault displacements at Sites 541 and 542. Circled numbers 1 to 7 refer to faults or possible faults. Fault throws are determined principally from restoration of nannofossil zones (Bergen, this volume). In addition, the throw on fault 2 is defined by correlation of paleomagnetic stratigraphy and ash layers; fault 2 is also marked by a change in bedding dips. Heavy line corresponds to the slice $1 /$ slice 2 boundary separating Tectonic Units A and B, as defined in the Site 541 report. 


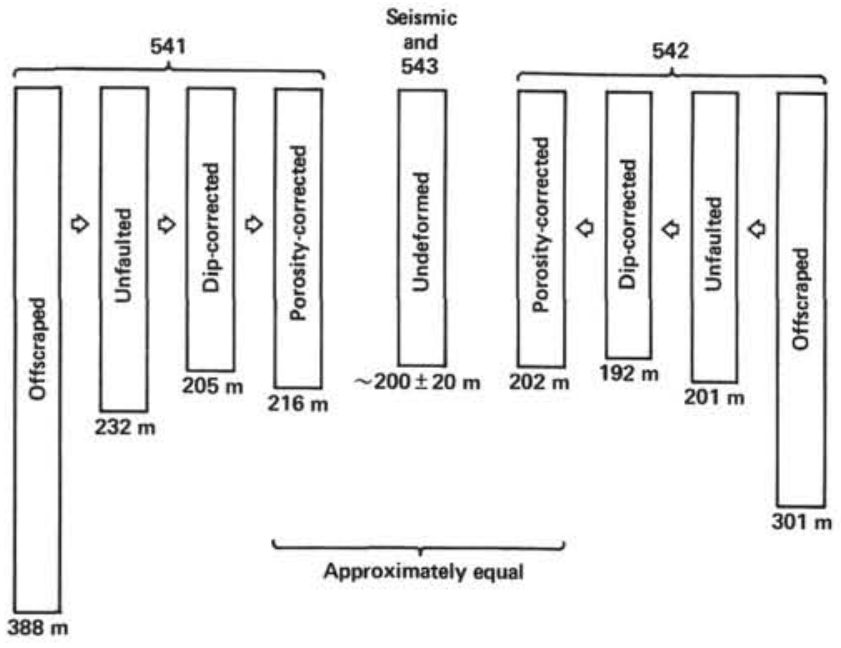

Figure 13. Thickness restoration for sections cored at Sites 541 and 542. Throws of faults taken from Figure 12.

thickness. The good correspondence between the reconstructed thicknesses and their probable undeformed equivalents suggests that the former include all major faults and provide a sound basis for construction of a cross section.

\section{Geologic Cross Section}

A geologic cross section through the Leg $78 \mathrm{~A}$ area provides a basis for comparison to other modern subduction zones and possible ancient equivalents on land (Fig. 14). As such, we have constructed a reasonably constrained but not necessarily unique cross section through Sites 541 and 542 along seismic Line A1D. This cross section has been developed from a manually prepared, true-scale depth section using velocity information obtained during drilling. This depth section provides control on the décollement surface extending beneath Site 542 and intersecting the base of Site 541 . Additionally the seismic data outline the shape of a 3$\mathrm{km}$-long, 200-m-thick slice of sediment that is being scraped off immediately seaward of the deformation front. Similar packages of sediment, caught in the act of being scraped off, are known in a number of areas, including the Nankai Trough (Karig, Kagami, et al., 1983), the Middle America Trench (Moore et al., 1982), and south of the drilling area along the Barbados Ridge (Discovery 109, Line 2, G. Westbrook, personal communication, 1983). Another constraint in section reconstruction consists of the major faults penetrated at about 270 $\mathrm{m}$ sub-bottom at Site 541 and near the base of Site 542 . We believe these faults bound major tectonic units of adjusted volume similar to the slice presently being scraped off. The dip of one of these faults as cored at $276 \mathrm{~m}$ sub-bottom is about $45^{\circ}$ once the effects of drilling deformation are removed. However, we believe the overall dip of these major faults is shallow. The dip of these faults is modeled after the low-angle fault that bounds the eastward limit of the slice presently being scraped off (Fig. 5A). We believe that minor stratigraphic inversions and tilted beds represent small-scale faults and folds that probably account for the required overall thickening of the major tectonic units. The thickness of slope sediments is estimated from a probable age of uplift and known sedimentation rates. The slope deposits are not resolvable seismically, and their boundary with the offscraped material is not apparent in the cores. Finally, the cross section is balanced in a volumetric sense; that is, the volume of tectonic slice 1 , on which we have fault control, is equivalent to the slice presently being scraped off, less the $25 \%$ volume reduction required by the porosity data.

The cross section (Fig. 14) exhibits relatively simple geometry and consists of two major tectonic units plus the sediment slice presently being scraped off. The tectonic slices show internal thickening but are not completely imbricated (or piggy-backed) one upon another. The cumulative shortening parallel to the décollement can be calculated from the total throw of all faults at Sites 541 and 542 . The average dip of the faults relative to the décollement is about $15^{\circ}$, as estimated for the eastern boundary of the slice presently being scraped off.

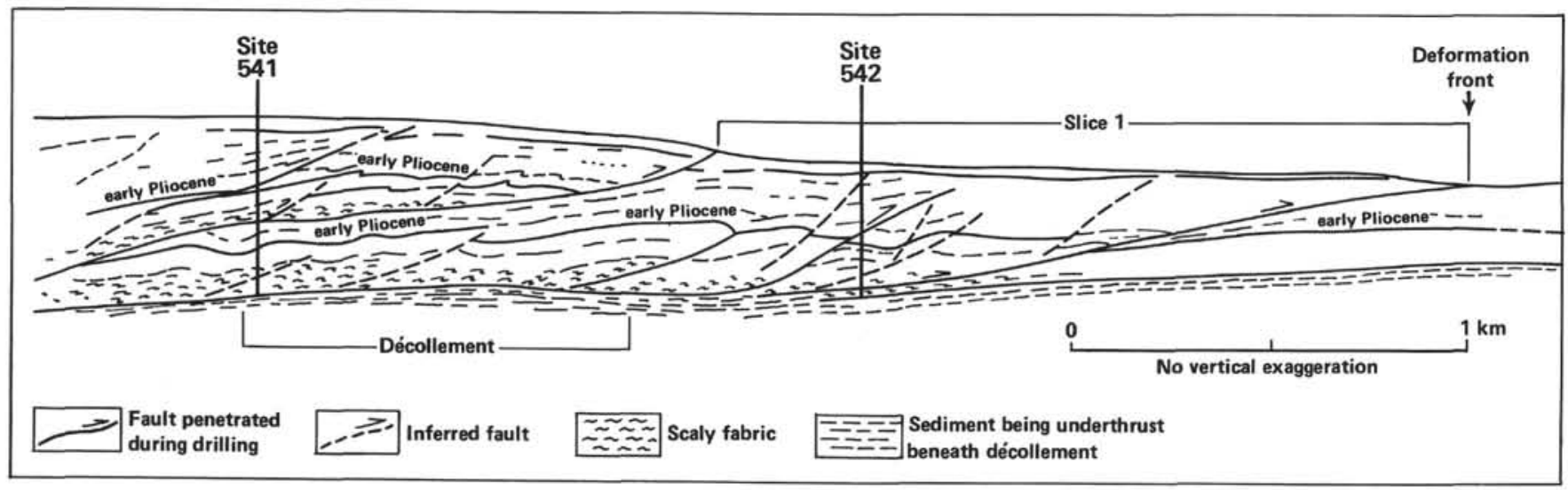

Figure 14. Geological cross section along A1D, through Sites 541 and 542, showing detail of offscraped unit. This cross section is based on drilling results, including paleomagnetically oriented bedding planes, and seismic reflection data. The cross section was drawn from a manually prepared depth section. The volume of slice 1 is similar to that of the one presently being scraped off seaward of the deformation front; hence, the cross section is volumetrically balanced. The surface outcrop of slice 1 is shown by a brace indicating its bounding faults. 
Accordingly the calculated shortening is about $1 \mathrm{~km}$. Given the uncertainty concerning the dip of the faults and their throw, this estimate could be in error by as much as $50 \%$.

\section{CONSEQUENCES OF STRUCTURAL GEOMETRY}

\section{Comparison of Shortening Rate and Convergence Rates}

Comparison of the shortening rate at Sites 541 and 542 to plate-tectonic and seismological estimates of convergence rates provides clues to the overall distribution of strain within the forearc region. The $1 \mathrm{~km}$ of shortening at Sites 541 and 542 must have occurred since 2.5 $\mathrm{Ma}$, as this is the age of the rocks overthrust at the boundary between tectonic slices 1 and 2 . A more probable age for the initiation of shortening at Site 541 is indicated by an exceptional concentration of sediment gravity flows, which died out upsection about $1.5 \mathrm{Ma}$. The cessation of gravity-flow deposition may indicate when the incoming sediment was uplifted from the base of slope environment and vigorous underthrusting was initiated. Alternatively, these gravity flows might also be generated by slumps extending some distance seaward of the deformation front (e.g., see Belderson et al., this volume). Lacking more definitive evidence, we estimate that the initiation of vigorous underthrusting began in the vicinity of Site 541 about $1.5 \pm 1 \mathrm{Ma}$.

Taking into account the uncertainty in both the amount and time of initiation of shortening, the shortening rate could range from 0.2 to $3 \mathrm{~km} / \mathrm{Ma}$ with a most likely value of $0.67 \mathrm{~km} / \mathrm{Ma}$. The upper limit of the shortening rate barely overlaps with the minimum seismic slip-rate of $2.5 \mathrm{~km} / \mathrm{Ma}$ inferred for the subduction zone (Figs. 15, 16). Moreover, the shortening rate at Sites 541 and 542 is but a small percentage of the $20-$ to $37-\mathrm{km} / \mathrm{Ma}$ convergence rate determined from plate tectonic considerations (Figs. 15, 16). The measured shortening at Sites 541 and 542 is significantly less than any estimate of plate convergence. Either our measurements of shortening are grossly in error, the estimated plate convergence rates are much too high, or the difference in convergence is being distributed elsewhere across the plate boundary.

Evidence for distributed strain across the forearc region is revealed in several seismic reflection studies. Folding and arcward-verging reverse faulting is observed at the boundary between the Barbados Ridge complex and the Tobago and Lesser Antilles troughs (Fig. 2; Westbrook et al., this volume). Moreover, a high-resolution seismic reflection profile across the southern extent of the Barbados Ridge complex indicates substantial shortening across the complex (Biju-Duval et al., 1982). Finally, a study of the structural thickening occurring above the décollement arcward of Sites 541 and 542 suggests the bulk of the shortening resulting from plate convergence is distributed west of the zone of initial offscraping (see discussions that follow). Substantial shortening landward of the toe of the trench slope also occurs at other forearcs where accretion is dominant (e.g., Karig et al., 1980; Moore et al., 1982; Karig, in press).

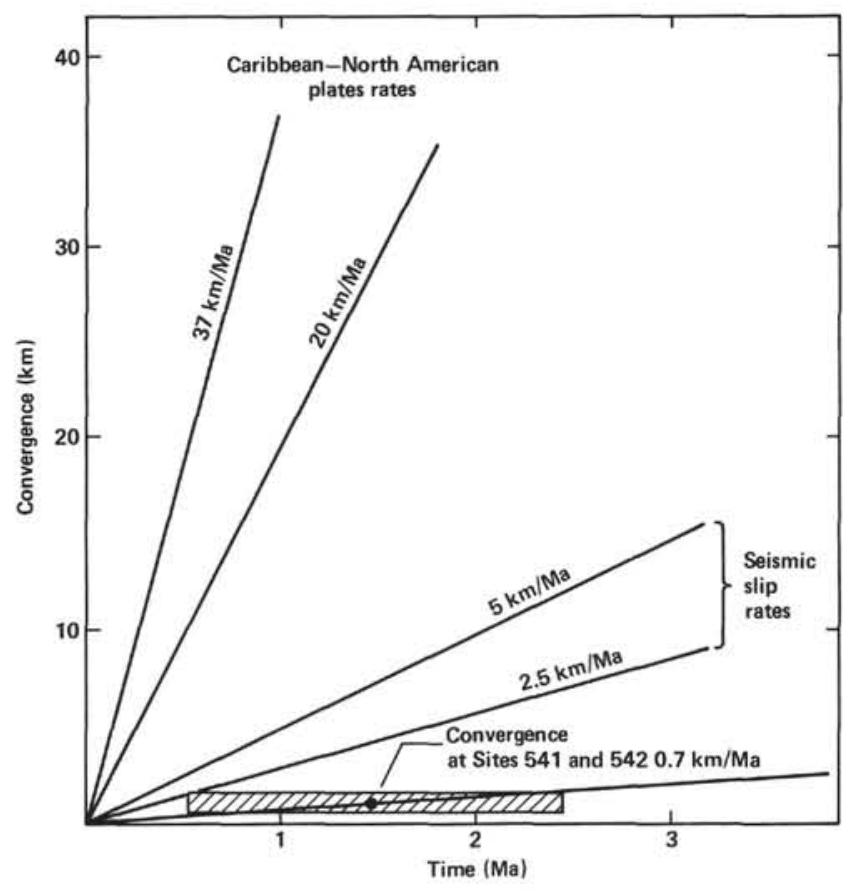

Figure 15. Plot of convergence rate as determined from plate models, seismicity, and offscraping within Leg 78A area. Low relative value of convergence at Sites 541 and 542 is probably the result of distributed shortening farther west in the accretionary prism. Low seismic slip rate is probably explained by aseismic slip. Higher ( 37 $\mathrm{mm} / \mathrm{yr}$.) plate tectonic rates are from Sykes et al., 1983; the 20$\mathrm{mm} / \mathrm{yr}$. rate is from Macdonald and Holcombe, 1978, and Minster and Jordan, 1978. Seismic slip rate from Molnar and Sykes, 1969; and Dorel, 1981).

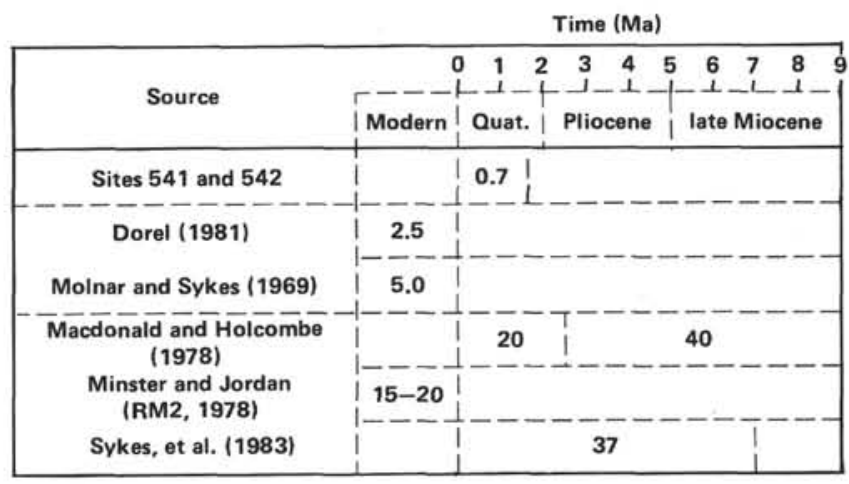

Figure 16. Estimated convergence rates $(\mathrm{km} / \mathrm{Ma})$ between the North American and Caribbean plates compiled from various sources. (RM2 in Minster and Jordan citation refers to specific model they discuss.) Numbers are plotted for whatever time interval they apply.

\section{Thickening of the Offscraped Unit}

Mechanism of Thickening. Seismic reflection profiles in the Leg 78A area consistently show thickening of the discontinuously reflective or offscraped unit west of the deformation front. The décollement and the subjacent acoustically layered sequence are continuous and undisturbed beneath the offscraped sediment in the drilling area; apparently no mass addition or underplating oc- 
curs by down-stepping of the décollement through the acoustically layered sequence (see Westbrook and Smith, 1983, for an example of down-stepping). Therefore, the observed thickening of the offscraped unit must involve the imbrication, tilting, or shortening of the offscraped sedimentary slices.

The specific mode and geometry of thickening in the offscraped unit are unknown. Nevertheless, the site-survey and drilling data provide some broad constraints: (1) The thickening process must operate within the narrow wedge defined by the water-bottom and the décollement but without mass addition from below the décollement. (2) The slices of offscraped material that are imbricated, tilted, and/or shortened should approximate the volume (adjusted for porosity) of the slice presently being scraped off. (3) The faults bounding the slices or groups of slices must be geometrically consistent with the shallow-dipping reflectors as seen in seismic Profile A1D.

Our conceptualization of possible thickening mechanisms is outlined in Figure 17. Figure 17A illustrates the true geometry of thickening above the décollement and the orientation of the shallowly dipping reflectors. In Figure 17B thickening is achieved by simple imbrication and landward tilting of offscraped slices. This first model, however, requires substantial tilting to obtain the observed thickness that would generate steeply dipping reflectors (either faults or bedding surfaces). A second model involves imbrication and modest landward tilting of individual offscraped slices, followed by secondary imbrication of packages of slices along shallowly dipping faults, which generate the observed reflections (Fig. 17C). A third model (Fig. 17D) allows significant variations in the volume of the offscraped slices, specifically permitting an increase in volume of slices to the west. As with the second model, this scenario requires initial imbrication and tilting of offscraped slices with secondary imbrication of packages of slices. Overall we favor the second model $(17 \mathrm{C})$ as the simplest explanation of the available data.

Rate of Thickening of Offscraped Unit. A measure of the distribution of strain arcward of the deformation front is provided by the differential thickening of the offscraped sediment above the unbroken décollement. The differential thickening of the offscraped material (total thickness less thickness of incoming material) has been documented along seismic Line A1D and along Discovery 109 Line 17 (Westbrook et al., this volume) (Fig. 18). The thickness was determined using the velocity function

$$
D=t[0.9+t(0.16)]
$$

where $D$ is depth and $t$, two-way traveltime. This velocity function, developed by $\mathrm{G}$. Westbrook, averages sonabouy data across the accretionary prism, it was used to construct a series of maps of depth to various sub-bottom horizons (Speed et al., in press). The plotted thicknesses do not make allowances for slope sediments, which are difficult to resolve; nor have we attempted to intro- duce any thickness modifications based on the expected consolidation of the deforming sediment mass.

The total differential thickness at any location probably records imbrication along shallowly dipping thrust faults plus small-scale intra-packet shortening. With continuous accretion each vertical column of the offscraped sedimentary sequence has evolved progressively by incremental thickening of the next seaward-most vertical column. Furthermore, if the rate of sediment input has been constant then the slope of the curve of differential structural thickening provides a measure of the rate of thickening at any point. The recent estimate of Sykes et al. (1983) (Fig. 16) indicates a constant rate of convergence back to $7 \mathrm{Ma}$. The thickness of incoming sediment may have been greater prior to and during the underthrusting of the Tiburon Rise, therefore the linear increase differential thickness (Fig. 18) is not considered significant. However, the area of Discovery 109 Line 17, located slightly north of the Tiburon Rise, probably has been underthrust by a uniform sediment thickness of the adjacent abyssal plain. Along this seismic line, the slope of the cumulative curve of differential structural thickening records the current rate of structural thickening across the accretionary prism. Expectably the rate decreases in an arcward direction. The decreased rate of deformation probably reflects the progressive strengthening of the accretionary complex by means of dewatering. A decreasing rate of deformation with distance from the toe of the trench slope is also documented off southern Mexico (Moore et al., 1982) and southwestern Japan (Karig, in press).

\section{Hydrogeology and Structural Geometry}

The extensive décollement imaged seismically (Westbrook et al., 1982) plus the drilling results suggest that near-lithostatic fluid pressures and high permeability exist at least along the décollement and the active thrust faults splaying from it. The interstitial water studies argue against rapid vertical fluid movement throughout the drilled stratigraphic section but permit abnormally high fluid pressures. Accordingly, the overpressured fluids probably move to the sea bottom mainly along active faults (Fig. 19). Westbrook and Smith (1983) have proposed that the high pressure fluids are transmitted beyond the deformation front to generate mud volcanoes. Both the underthrust acoustically layered sequence and the overlying offscraped and underplated sediment probably provide sources of fluid.

The inadvertent packer experiment and theoretical considerations suggest that fluid pressures in the active faults are not less than 80 and may approach $97 \%$ of the lithostatic load (Westbrook et al., 1982; Davis, this volume). The lithostatic load that the abnormal fluid pressure must balance increases arcward along the décollement as the accretionary prism thickens. Accordingly, fluid should migrate up the décollement. Discovery 109 seismic Section 17 (Westbrook et al., this volume), just north of the drilling, images the décollement to $72 \mathrm{~km}$ landward of the deformation front. At the arcward limit of this seismic line, the total load (water plus accretion- 


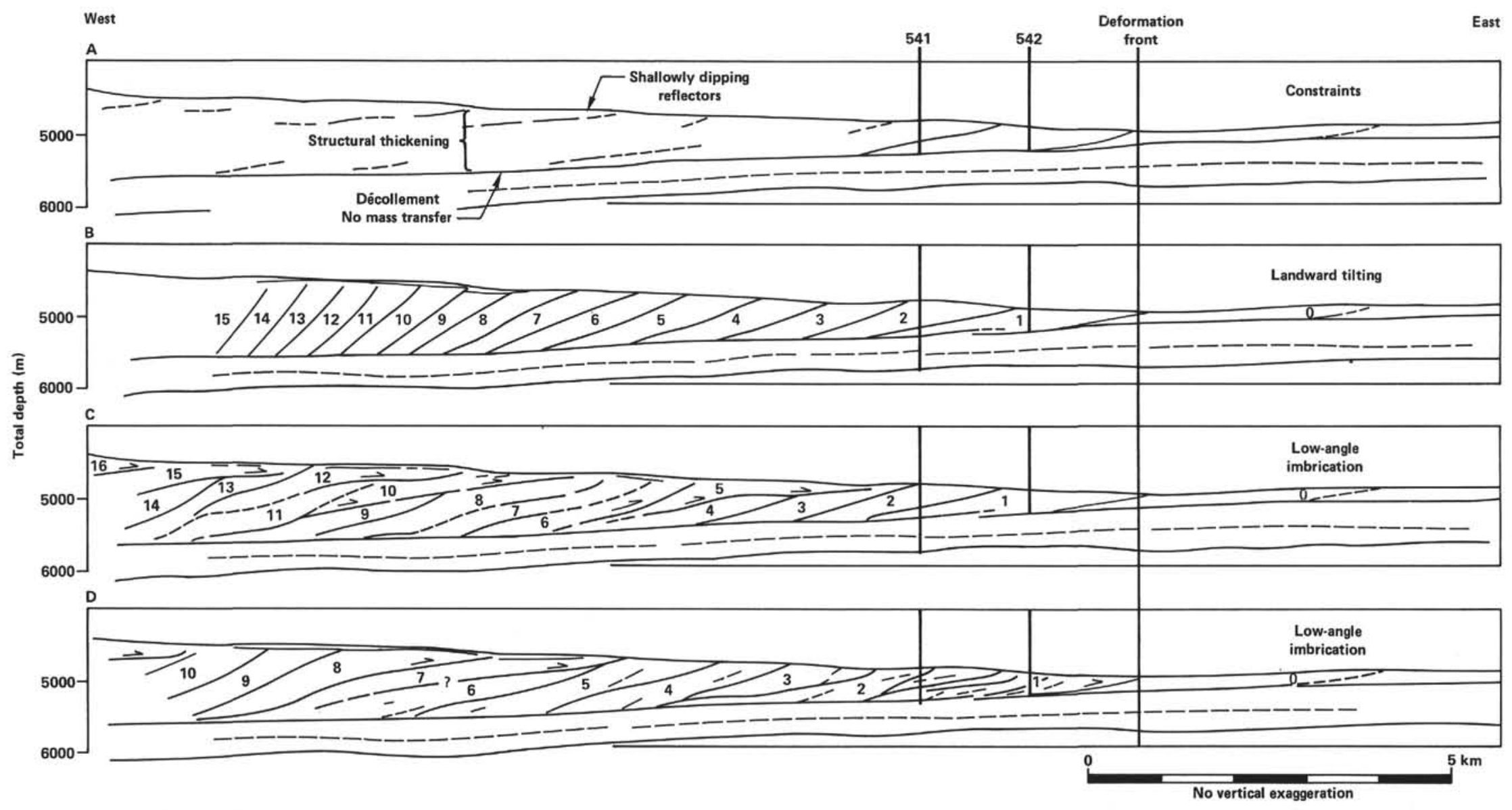

Figure 17. Extended geological cross sections. A. Depth section with shallowly dipping reflectors showing the data constraining reconstructions B, C, and D (which show sediment package numbers [slices] beginning with 0 , which is presently being scraped off). B. Simple model of imbrication and landward tilting. This configuration produces steeply tilted layers that are not consistent with the shallowly dipping reflectors. C. Model of imbrication and landward tilting with secondary imbrication along shallowly dipping faults. This model is favored by the authors. D. Model as in C, but with significant variation in volumes of offscraped slices. 


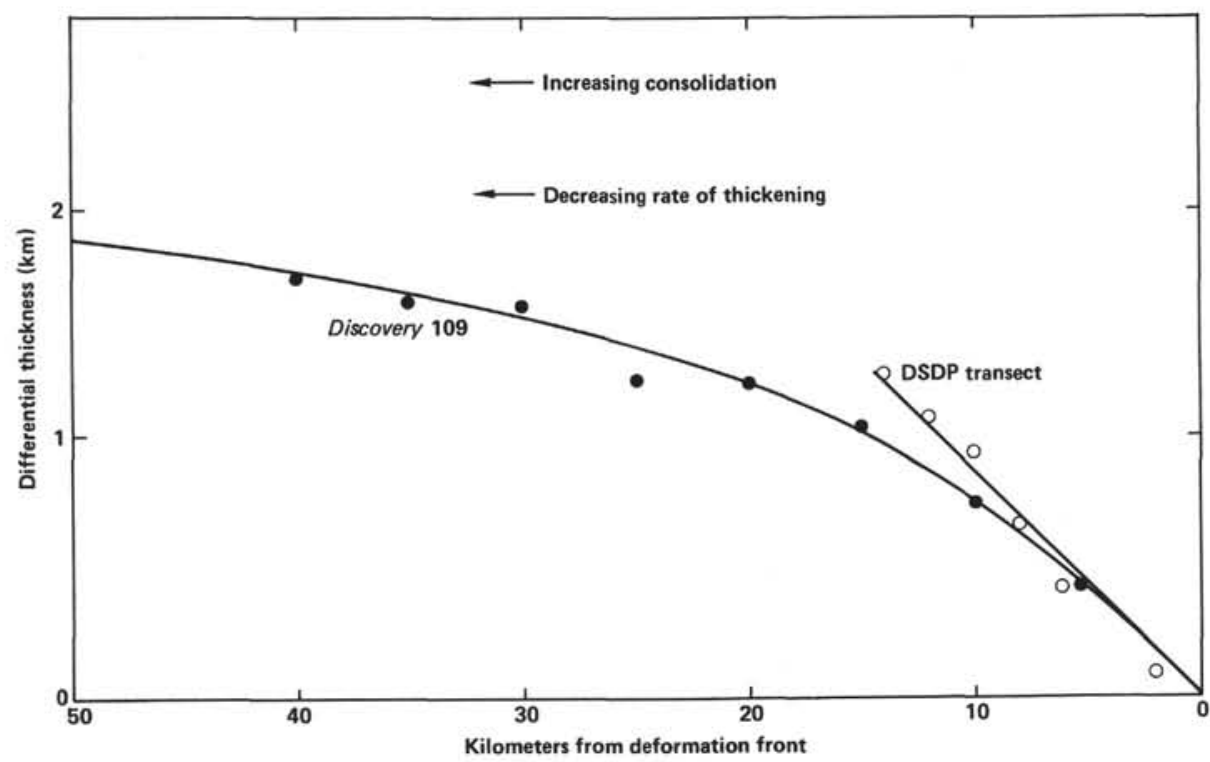

Figure 18. Plot of differential thickening versus distance arcward of the deformation front. The differential thickness at any point is equivalent to the vertical depth to the décollement less the thickness of sediment incoming on the oceanic plate. In the absence of underplating from below the décollement, the differential thickness represents cumulative fault throw at any point. Note that the rate of thickening dies off landward on the Discovery 109 line, indicating a decreasing rate of deformation.

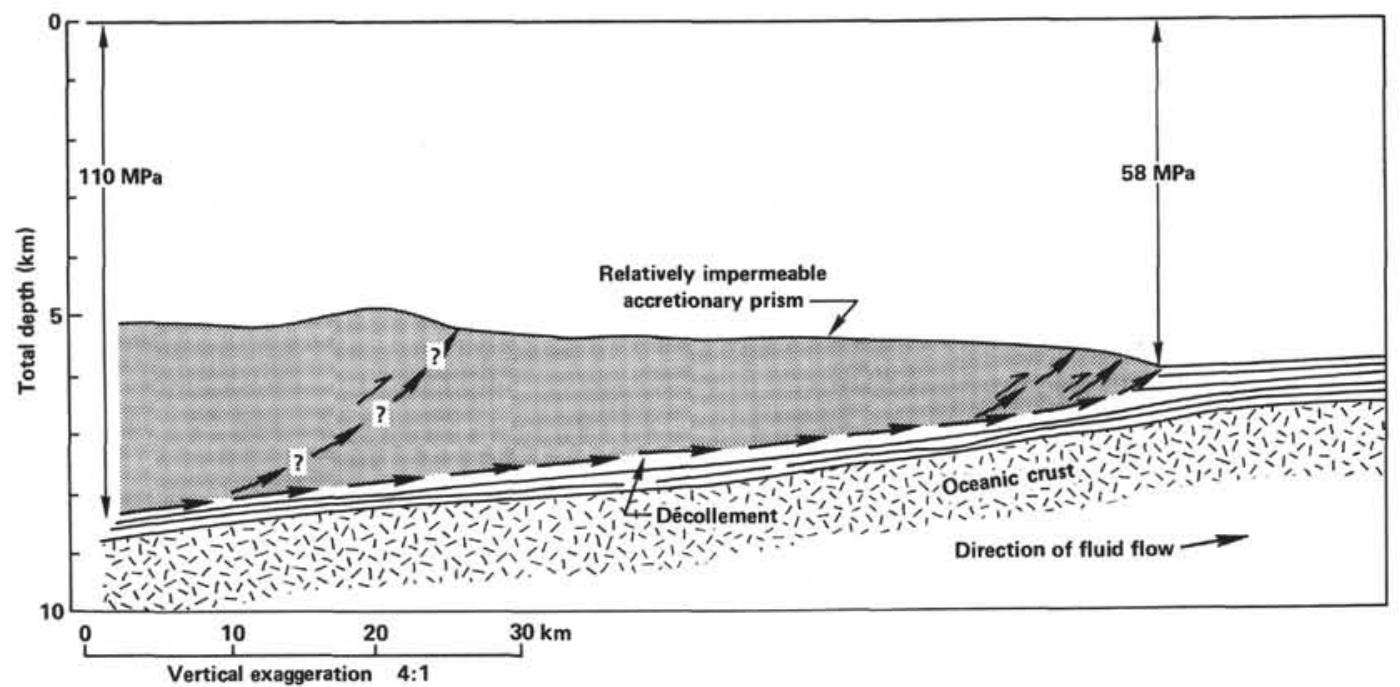

Figure 19. Schematic of fluid pressure movement near Leg 78A area. For underthrusting to occur along the décollement the fluid pressure must be approximately equal to the total water-rock overburden. This pressure increases to the west because of the increasing thickness of the accretionary prism; limiting values are shown. The systematic pressure difference along the décollement causes fluid flow to the east up to the décollement, with fluid escape along active thrust splays. The expelled fluid may originate from the underthrust sediment beneath the décollement as well as the overlying accretionary prism. The depth section shown in this diagram was generated from Discovery 109 Line 17 (Westbrook et al., this volume).

ary prism) is about $110 \mathrm{MPa}$, whereas at the deformation front the total pressure is approximately equivalent to the water pressure or about $58 \mathrm{MPa}$ (Fig. 19). Therefore, the total pressure drop is about $52 \mathrm{MPa}$ along the extent of the décollement imaged on Line 17, and the pressure gradient is about $7.2 \times 10^{2} \mathrm{~Pa} / \mathrm{m}$ along the décollement.

\section{COMPARISONS TO OTHER ACTIVE MARGINS AND FOLD AND THRUST BELTS}

The imbrication of the offscraped sediments, the long décollements, and their down stepping (Westbrook and Smith, 1983) define a structural style similar to that in fold and thrust belts (e.g., Price, 1981). Other modern 
subduction zones including the Nankai Trough (Nasu et al., 1982) and northernmost California (Biddle and Seely, in press) reveal similar structural styles dominated by décollements and imbricate thrusting. The improving quality of seismic data may yet pinpoint additional modern subduction zones with similar fold and thrust style structure, especially in areas characterized by lower plates with thick sequences of incoming sediment.

In spite of the fact that fold and thrust style structure is being increasingly recognized in modern subduction zones, ancient uplifted accretionary sequences exhibit complicated structural styles (e.g., Speed and Larue, 1982; Maxwell, 1981; von Huene et al., 1979). This discrepancy probably results from the continuing deformation of the accretionary prism subsequent to initial offscraping and underplating relatively near the deformation fronts of subduction zones. In other words, the initial fold and thrust style of deformation at some modern subduction zones may simply be a transient structural state of the deforming, partially lithified sediments. Apparently, this early state of deformation is rarely, if ever, preserved, lithified, and uplifted for subaerial inspection. Conversely, fold and thrust belts typically entrain lithified rocks with the fold and thrust style of deformation representing their final state of deformation.

\section{REGIONAL IMPLICATIONS OF LEG 78A RESULTS}

The Leg 78A drilling and related seismic reflection studies have been concentrated in the zone of initial accretion and have yielded results principally of topical interest. Nevertheless, aspects of our results bear on regional geodynamic problems.

\section{Regional Sedimentology}

One of the most notable aspects of the Leg 78A cores is the complete lack of terrigenous turbidites, which marks the Leg $78 \mathrm{~A}$ areas as a compositionally unusual subduction complex, in contrast with known sediment types underthrusting the Barbados Ridge complex elsewhere. The sediment on the Atlantic seafloor south of the Leg $78 \mathrm{~A}$ area commonly includes terrigenous turbidites, as documented by piston coring and seismic facies studies (Wright, this volume). Terrigenous sand beds up to 50 $\mathrm{cm}$ thick extend at least as far north as DSDP Site 27 (Bader, Gerard et al., 1970), which lies at about the same latitude as the Leg 78A area (Fig. 1). Apparently the Tiburon Rise diverts northward flow of terrigenous sediment from South America. As the Leg 78A area is on the northern flank of this topographic barrier, the drill sites have been laterally shielded from southerly derived terrigenous flow and elevated above any turbidites flowing around the eastern termination of this Rise.

Middle(?) to upper Miocene clays are involved in a variety of tectonic phenomena all along the Barbados Ridge. In the Leg 78A area these clays are smectitic, undercompacted, and provide a preferential horizon for thrust fault and décollement development. Indeed the underthrusting of weak sediment along the extensive décollement in the Leg 78A area could not be achieved without the high pore pressures (see Westbrook et al.,
1982; Davis, this volume) at least partly attributable to the dewatering of the middle(?) to upper Miocene clays. South of the Leg 78A area, diapiric features interpreted as mud volcanoes may also be generated from upper Miocene smectitic muds (Mascle et al., in press; Biju-Duval et al., 1982; Fontas, et al., this volume; Westbrook and Smith, 1983).

Rapidly accumulated clays near continental margins may be undercompacted and become diapirically active. The overall decrease in intensity of observed diapirism north of the South American continental margin is consistent with this generalization. Geophysical studies indicate undercompacted clays at passive margins may be involved in diapirism, listric normal growth faulting, and gravity-driven thrust faulting (Fig. 20). Some of the features observed beneath the southern Barbados Ridge may therefore reflect gravitationally induced mobility of the diapiric clay; however, the absence of growth faulting argues against the dominance of extensional processes. In the Leg 78A are the late Miocene sediment accumulation rates approach those typical of open-ocean settings (Wright, Sediment Accumulation Rates chapter, this volume). Apparently the smectitic nature of these clays encouraged undercompaction and structural incompetence.

\section{Magmatic Activity and Subduction}

A significant result of the Leg 78A drilling is the documentation of the chronology of ash beds that presumably record magmatic activity of the Lesser Antilles volcanic arc (Natland, this volume). However, as the ash beds are produced only by explosive volcanism, they do not measure the total eruptive history. In addition to providing clues to the volcanic arc activity, the ash beds have been used as a valuable correlative tool for measuring throws on faults (see Site 541 report, this volume; Natland, this volume).

The abundance of ash beds during the latest Miocene and earliest Pliocene corresponds with known periods of pronounced volcanism in the Lesser Antilles (Westercamp, 1977). An early to middle Miocene peak in ash bed frequency is documented by well-dated radiolarian assemblages at Site 543; however, this period of magmatic activity is not clearly defined in the Lesser Antilles. It is noteworthy that the middle to late Miocene decrease in magmatic activity as defined by the Leg 78A cores may correspond to a $50 \mathrm{~km}$ westward shift of the volcanic front in the northern Lesser Antilles (Bouysse et al., this volume).

Volcanic and volcaniclastic rocks of the Lesser Antilles and ash beds from the Island of Barbados indicate an intense pulse of volcanism occurred from middle Eocene to early Miocene (Speed and Larue, 1982). The ash beds from the Island of Barbados undeniably signify explosive activity, yet only thin scattered middle Eocene through upper Oligocene ash beds are known from the Leg 78A drill holes. The thin wispy lower Eocene ash beds at Site 543 might represent the inception of magmatism in the Lesser Antilles or, alternatively, the welldocumented coeval volcanism in the Greater Antilles. The lack of a conspicuous pre-Miocene ash sequence at 


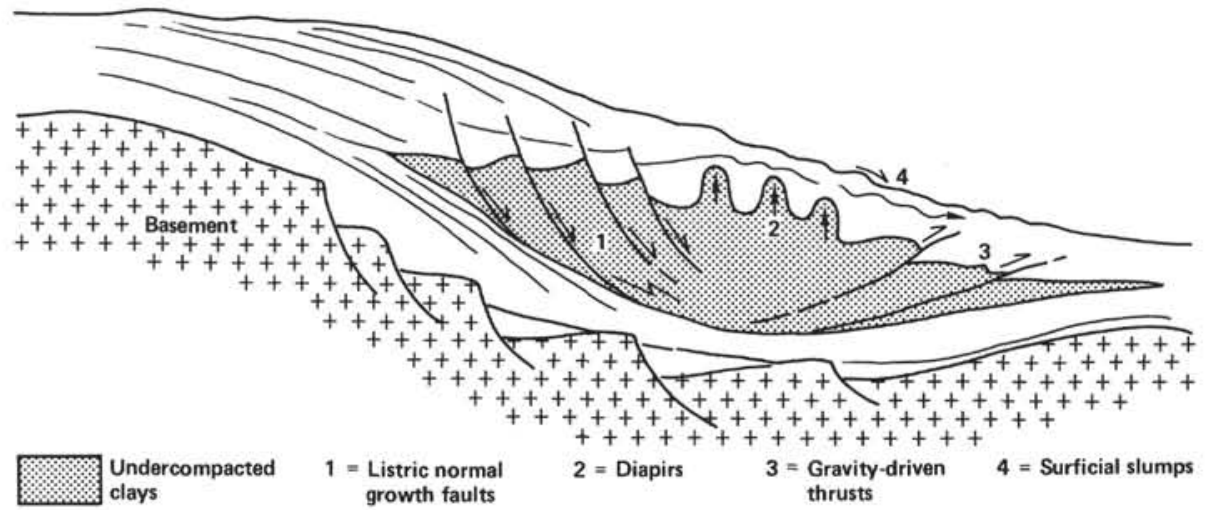

Figure 20. Types of deformation occurring in a thick sedimentary wedge with undercompacted clays in a passive margin setting. Some of the deformational effects observed along the southern Barbados Ridge complex could be partially caused by gravitational effects of the extensive sedimentary accumulation.

Site 543 may be a consequence of its remoteness from the magmatic arc at that time.

\section{Correlation to Barbados Island}

On Barbados Island, the Paleocene through middle Eocene Scotland Formation (Senn, 1940; terrigenous suite of Speed and Larue, 1982) accumulated in a deep-sea environment, probably below the CCD (Saunders, in press; Pudsey and Reading, 1982). Because of the imbrication and stratal disruption of this deep-water terrigenous suite, Speed and Larue (1982) believe that it represents offscrapings from the incoming plate. Alternatively, this terrigenous suite could represent a deformed midslope turbidite accumulation, as observed in the present Lesser Antilles forearc (Biju-Duval et al., 1982). Equivalent Eocene rocks at Site 543 are pelagic clays that probably accumulated under oceanic conditions far east of the Caribbean Plate boundary. These clays accumulated rapidly and are rich in smectite, in comparison to immediately younger and older deposits (Latouche and Maillet, this volume; Pudsey, this volume); they may reflect the coeval terrigenous sediment influx on Barbados. Because of their smectite enrichment, these Eocene deposits may provide the horizon of secondary décollement development imaged seismically by Westbrook and Smith (1983). The upper Miocene to Quaternary hemipelagic sediments, free of terrigenous turbidites, are presently being scraped off in the Leg 78A area, in contrast to both the terrigenous sediment now being accreted east of Barbados and that previously accreted to form the terrigenous suite of Barbados Island. The slope apron now accumulating in the Leg $78 \mathrm{~A}$ area resembles part of the pelagic suite (Oceanic Formation) overlying the terrigenous deposits of Barbados Island (Speed and Larue, 1982).

\section{SUMMARY}

The principal conclusions of our tectonic synthesis are:

1. In the Leg $78 \mathrm{~A}$ area the upper $200 \mathrm{~m}$ of the sediment on the incoming oceanic plate is scraped off at the deformation front, with sediment below being underthrust to unknown depths.
2. Thrust faulting comprises the most conspicuous structural element of the offscraped sediment wedge.

3. Biostratigraphically constrained offsets along the thrust faults suggest that only a small percentage of the total convergence is taken up in the Leg $78 \mathrm{~A}$ drilling area. Apparently much additional shortening must be distributed landward across the accretionary prism.

4. Part of the shortening arcward of the Leg 78A area occurs by structural thickening of the offscraped sediment wedge above an unbroken décollement. This mode of thickening locally extends to $45 \mathrm{~km}$ arcward of the deformation front and is partially accomplished by low-angle imbrication of the thrust slices initially scraped off in the Leg 78A area.

5. The décollement separating the offscraped and underthrust sedimentary packages initially forms between an anomalously porous, weak smectitic mud, and a stronger, more dense, and less porous radiolarianbearing mud. Thrust faults also occur preferentially in the weak smectitic clay, indicating pronounced stratigraphic control on structural style.

6. Near lithostatic fluid pressure as measured on a thrust splaying off the décollement apparently reduces the effective confining stress across faults and permits extensive underthrusting of sediments beneath the décollement. The high fluid pressure also explains why anomalously high temperatures were observed at shallow depths at Site 541 .

7. The lack of uniform advection of fluids through the largely impermeable sedimentary column and the apparently high fracture permeability of active faults suggest that fluid movement is concentrated along the décollement and thrust faults splaying off of it.

8. The offscraped sedimentary sequence in the Leg $78 \mathrm{~A}$ area lacks terrigenous turbidites and therefore is unlike apparently accreted deposits composing the basement of the Island of Barbados as well as most subaerially exposed accretionary prisms elsewhere. The underthrust sedimentary sequence in the Leg $78 \mathrm{~A}$ area is principally pelagic in origin.

9. The overall structural style of the Leg 78A area and areas near the deformation front farther south along the Barbados Ridge complex is similar to that of 
classic fold and thrust belts. This structural style is not maintained during continuing evolution, as evidenced from the basement rocks of the Island of Barbados; nor is fold and thrust style deformation apparent in almost any subaerially exposed accretionary prism. Shortening continuing throughout the consolidation of the sediments initially composing accretionary prisms must account for their stratal disruption and otherwise complex structural style. Fold and thrust belt geometry constitutes a transient state in the structural evolution of accretionary prisms.

\section{ACKNOWLEDGMENTS}

We acknowledge the governments of the Federal Republic of Germany, France, Great Britain, Japan, USSR, and USA for support of IPOD. During the cruise both the marine and drilling crews of the Glomar Challenger and the DSDP technical staff were cooperative in all respects. Finally, we owe a great debt to our fellow scientists on whose work this tectonic synthesis largely rests. Moore's efforts in the analysis of cruise data and manuscript preparation were supported by National Science Foundation Grant OCE 81-10394. Roland von Huene, Graham Westbrook, and Neil Lundberg provided excellent critical reviews.

\section{REFERENCES}

Aubouin, J., von Huene, R., et al., 1982. Init. Repts. DSDP, 67: Washington (U.S. Govt. Printing Office).

Bader, R. G., Gerard, R. D., et al., 1970. Init. Repts. DSDP, 4: Washington (U.S. Govt. Printing Office).

Barron, J. A., Poore, R. Z., and Wolfart, R., 1981. Biostratigraphic summary, Deep Sea Drilling Project Leg 63. In Yeats, R. S., Haq, B. U., et al., Init. Repts. DSDP, 63: Washington (U.S. Govt. Printing Office), 927-941.

Berger, W. H., 1977. Carbon dioxide excursion and the deep-sea records: aspects of the problem. In Anderson, N. R., and Malhoff, A. (Eds.), The Fate of Fossil Fuel $\mathrm{CO}_{2}$ in the Oceans: Plenum Press (New York), pp. 505-542.

Biddle, K. T., and Seely, D. R., in press. Structure of a subduction complex, offshore Northern California. In Bally, B. (Ed.), Seismic Expression of Structural Styles (Vol. 3), Am. Assoc. Pet. Geol. Stud. Geol. (No. 15).

Biju-Duval, G., Mascle, A., Montadert, L., Wannesson, J., 1978. Seismic investigations in the Columbia, Venezuela and Grenada Basins and on the Barbados Ridge for future IPOD drilling. Geol. Mijnbouw, 57:105-116.

Biju-Duval, B., Le Quellec, P., Mascle, A., Renard, V., and Valery, P., 1982. Multibeam bathymetric survey and high resolution seismic investigations of the Barbados Ridge complex (Eastern Caribbean): a key to the knowledge and interpretation of an accretionary wedge. In Le Pichon, X., Augustithis, S. S., and Mascle, J. (Eds.), Geodynamics of the Hellenic Arc and Trench, Tectonophysics, 86: 275-304.

Chase, R. L., and Bunce, E. T., 1969. Underthrusting of the eastern margin of the Antilles by the floor of the western North Atlantic Ocean, and the origin of the Barbados Ridge. J. Geophys. Res., 74:1413-1420.

Dorel, J., 1981. Seismicity and seismic gap in the Lesser Antilles arc and earthquake hazard in Guadeloupe. Geophys. J. R. Astron. Soc., 67:679-695.

Hussong, D., Uyeda, S., et al., 1982. Init. Repts. DSDP, 60: Washington (U.S. Govt. Printing Office).

Karig, D. E., in press. The framework of deformation in the Nankai Trough. In Kagami, H., Karig, D. E., et al., Init. Repts. DSDP, 87: Washington: (U.S. Govt. Printing Office).

Karig, D. E., Kagami, H., et al., 1983. Varied responses to subduction in Nankai Trough and Japan Trench forearcs. Nature, 304:148-151.

Karig, D. E., Moore, G. F., Curray, J. R., and Lawrence, M. B., 1980. Morphology and shallow structure of the lower trench slope off Nias Island, Indonesia. In Hays, D. E. (Ed.), Tectonic and Geologic Evolution of Southeast Asian Seas and Islands, Am. Geophys. Union Geophys. Monograph, 23:179-208.
Macdonald, K. C., and Holcombe, T. L., 1978. Inversion of magnetic anomalies and seafloor spreading in the Gayman Trough. Earth Planet. Sci. Lett., 40:407-414.

Mascle, A., Lajat, D., and Nely, G., in press. Sediments deformation linked to subduction and to argillokinesis in the southern Barbados Ridge from multichannel seismic surveys. Trans. 4th LatinAmerican Geol. Cong.

Maxwell, J. C., 1981. Geologic cross sections, northern California Coast Ranges to northern Sierra Nevada, and Lake Pillsbury area to southern Klamath Mountains. Geol. Soc. Am. Map and Chart Series, MC-28N.

Minster, J. B., and Jordan, T. H., 1978. Present-day plate motions. J. Geophys. Res. 83:5331-5354.

Molnar, P., and Sykes, L. R., 1969. Tectonics of the Caribbean and Middle America regions from focal mechanisms and seismicity. Geol. Soc. Am. Bull., 80:1639-1684.

Moore, J. C., Watkins, J. S., McMillen, K. J., Bachman, S. B., Leggett, J. K., et al., 1982. Facies belts of the Middle America Trench and forearc region, southern Mexico: results from Leg 66 DSDP. In Leggett, J. K. (Ed.), Trench-Forearc Geology, Spec. Publ. Geol. Soc. London, pp. 77-94.

Nasu, N., Tomoda, Y., Kobayashi, K., Kagami, H., Uyeda, S., et al., 1982. Multi-channel seismic reflection data across Nankai Trough. IPOD-Japan Basic Data Series, No. 4, Ocean Research Institute, University of Tokyo.

Price, R. A., 1981. The Cordilleran foreland thrust and fold belt in the southern Canadian Rocky Mountains. In McClay, K. R., and Price, N. J. (Eds.), Thrust and Nappe Tectonics, Geol. Soc. London Spec. Publ. No. 9, London (Blackwells), pp. 427-448.

Pudsey, C. J., and Reading, H. G., 1982. Sedimentology and structure of the Scotland Group, Barbados. In Leggett, J. K. (Ed.), TrenchForearc Geology, Geol. Soc. London Spec. Publ. No. 10. pp. 291-308.

Saunders, J. B., in press. Field trip guide: Barbados. Trans. 4th Latin American Geol. Congr.

Scholl, D. W., von Huene, R., Vallier, T. L., and Howell, D. G., 1980. Sedimentary masses and concepts about tectonic processes at underthrust ocean margins. Geology, 8:564-568.

Senn, A., 1940. Paleogene of Barbados and its bearing on history and structure of Antillean-Caribbean region. Am. Assoc. Pet. Geol. Bull. 24:1548-1610.

Speed, R. C., and Larue, D. K., 1982. Barbados: architecture and implications for accretion. J. Geophys. Res. 87:3633-3643.

Speed, R. C., Biju-Duval, B., Ladd, J. W., Mascle, A., Moore, J. C., et al., in press. Lesser Antilles Arc system and adjacent terranes. Joint Oceanographic Institutions Report on Data Synthesis in Ocean Margin Drilling Program Area 10.

Sykes, L. R., McCann, W. R., and Kafka, A. L., 1983. Motion of Caribbean Plate during last 7 million years and implications for earlier Cenozoic movements. J. Geophy. Res. 87(10):656-10,676.

Tomblin, J. F., 1975. The Lesser Antilles and Aves Ridge. In Nairn, A. E. M., and Stelhi, F. (Eds.), The Ocean Basins and Margins (Vol. 3): New York (Plenum Press), 1-64.

von Huene, R., Langseth, M., Nasu, N., and Okada, H., 1980. Summary, Japan Trench Transect. In Scientific Party, Init. Repts. DSDP, 56, 57, Pt 1: Washington: (U.S. Govt. Printing Office), 473-488.

von Huene, R., and Lee, H., 1983. The possible significance of pore fluid pressures in subduction zones. In Watkins, J. S., and Drake, C. L. (Eds.), Studies in Continental Margin Geology: Am. Assoc. Pet. Geol. Mem. 34:781-791.

von Huene, R., Moore, G., and Moore, J. C., 1979. Cross section, Alaska Peninsula, Kodiak Island, Aleutian Trench. Geol. Soc. Am. Map and Chart Series, MC 28A.

Watkins, J. S., Moore, J. C. et al., 1982. Init. Repts. DSDP, 66: Washington (U.S. Govt. Printing Office).

Watkins, J. S., Moore, J. C., Shipley, T., Bachman, S. B., Leggett, J. K., et al., 1981. Accretion, underplating, and tectonic evolution, Middle America Trench, southern Mexico: results from Leg 66 DSDP. In Blanchet, R., and Montadert, L. (Eds.), Geology of Continental Margins, Colloque 3, 26th. Int. Geol. Congr., Paris, Oceanol. Acta, pp. 213-224.

Westbrook, G. K., 1982. The Barbados Ridge complex: tectonics of a mature forearc system. In Leggett, J. K. (Ed.), Trench-Forearc Geology, Spec. Publ. Geol. Soc. London, pp. 275-290. 
Westbrook, G. K., Bott, M. P. H., and Peacock, J. H., 1973. Lesser Antilles subduction zone in the vicinity of Barbados. Nature: Phys. Sci., 244:118-120.

Westbrook, G. K., and Smith, M. J., 1983. Long décollements and mud volcanoes: evidence form the Barbados Ridge complex for the role of high pore-fluid pressure in the development of an accretionary complex. Geology, 11:279-283.

Westbrook, G. K., Smith, M. J., Peacock, J. H., and Poulter, M. J., 1982. Extensive underthrusting of undeformed sediment beneath the accretionary complex of the Lesser Antilles subduction zone. Nature, 300:625-628.

Westercamp, D., 1977. Evolution des suies volcaniques de Martinique (FWI) et des arcs insulairs des Petites Antilles dan les contexts structural. Trans. 8th Caribbean Geol. Conf., Willemstad, pp. 227-228.

Date of Initial Receipt: July 1, 1983

Date of Acceptance: October 11, 1983 